\title{
Evaluating water quality and ecotoxicology assessment techniques using data from a lead and zinc effected upland limestone catchment
}

\author{
Magaly Valencia-Avellan ${ }^{1}$, Rebecca Slack ${ }^{2}$, Anthony Stockdale ${ }^{3}$, Robert John \\ George Mortimer ${ }^{4}$
}

${ }^{1}$ water@leeds, School of Geography, University of Leeds, Leeds LS2 9JZ, UK.

${ }^{2}$ The Royal Horticultural Society, Harlow Carr, Crag Lane, Beckwithshaw, Harrogate, North Yorkshire, HG3 $1 Q B$.

${ }^{3}$ School of Earth \& Environment, University of Leeds, Leeds LS2 9JZ, UK

${ }^{4}$ School of Animal, Rural and Environmental Sciences, Nottingham Trent University, Brackenhurst

Campus, Southwell, Nottinghamshire, NG25 0QF, UK.

E-mail contact: magyvalencia80@gn il.com

\section{Abstract}

Point and diffuse sources associated with historical metal ore mining are major causes of metal pollution. The understanding of metal behaviour and fate has been improved by the integration of water chemistry, metal availability and toxicity. Efforts have been devoted to the development of efficient methods of assessing and managing the risk posed by metals to aquatic life and meeting national water quality standards. This study focuses on the evaluation of current water quality and ecotoxicology techniques for the metal assessment of an upland limestone catchment located within a historical metal (lead ore) mining area in northern England. Within this catchment, metal toxicity occurs at circumneutral $\mathrm{pH}$ (6.2-7.5). Environmental Quality Standards (EQSs) based on a simple single concentration approach like hardness based EQS (EQS-H) are more overprotective, and from sixteen sites monitored in this study more than twelve sites (> 75\%) failed the EQSs for $\mathrm{Zn}$ and $\mathrm{Pb}$. By increasing the complexity of assessment tools (e.g. bioavailability-based (EQS-B) and WHAM- $F_{\text {TOx }}$ ), less conservative limits were provided, decreasing the number of sites with predicted ecological 
risk to seven (44\%). Thus, this research supports the use of bioavailability-based approaches and their applicability for future metal risk assessments.

Keywords: water quality standards, bioavailability, ecotoxicology, metal assessment, river water, limestone catchment

\section{Introduction}

Humans have impacted upland catchments for centuries through the process of mining. Exposure of metal-bearing minerals to oxygen and water, both subsurface and through dumping of mine wastes above the surface, can result in increased dissolved concentrations of metals in water bodies. Once metals have entered aquatic ecosystems, they interact with a broad spectrum of biotic and abiotic components via dynamic interrelated processes, resulting in a large variety of compounds (Luoma and Rainbow, 2008)

In natural waters, the behaviour of metals depends on their speciation. Such species include free ions, inorganic complexes, organic complexes, and metal sorbed to or incorporated within colloids or particulate matter. The formation of metal complexes depends on the concentration of all dissolved components, pH, and ionic strength (Namieśnik and Rabajczyk, 2010). Free metal ions can bind to dissolved organic matter (DOM; particularly humic acids), forming complexes that regurate the concentrations of metals available for interaction with organisms (Tipping, 2002). The complexity of these interactions in aquatic environments makes it difficult to measure the distribution of chemical forms. Knowledge of chemical speciation is important because the relative distribution of different forms controls metal interactions with organisms, including toxic effects. For instance, dissolved metals, particularly free metal ions, have been related to freshwater ecotoxicity (Campbell, 1995; De Schamphelaere and Janssen, 2002). More recently, the concentration predicted to be bound to humic acid has been found to be a good proxy for both organism body burdens (Stockdale et al., 2010; He and Van Gestel, 2015) and accumulation by aquatic bryophytes (Tipping et al., 2008). 
In the last few decades, a variety of in situ analytical approaches have been developed to understand the dynamics of metals in natural waters (Buffle and Horvai, 2000). One such technique is Diffusive Gradients in Thin-films (DGT) for assessing a range of active species, depending upon their mobility (diffusion coefficients) and kinetics (dissociation rates) across a thin film of polyacrylamide gel (Zhang and Davison, 2015). This technique has being used as a monitoring tool for providing kinetic information on labile metal species in rivers, soil or sediment impacted by mines and coastal waters (Unsworth et al., 2006; Warnkenet al., 2009). In addition, DGT has been applied to investigate potential metal availability in freshwater ecosystems, for instance the accumulation of cadmium in communities of algae (periphyton) has been evaluated by Bradac et al. (2009).

In view of the importance of DOM in complexing metals, comprehensive speciation models have been developed for predicting the distribution of chemical species accounting for complexation with inorganic and organic ligands as well as competition for organic binding sites between different metals, and between metals and protons. The Non-Ideal Competitive Adsorption (NICA) coupled with a Donnan electrostatic sub-model uses a continuous distribution approach to describe metal and proton bindings to organic matter (Benedetti et al., 1995; Kalis et al., 2006). A discrete site approach is used in the Humic lon Binding Model VII (Tipping et al., 2011), This is coupled with an inorganic thermodynamic code, the Windermere Humic Aqueous Model (WHAM) (Tipping, 1994). The WHAM code has been successfully applied in a variety of research and regulatory areas related to water quality criteria for zinc and copper in the United States and Europe (Hamilton-Taylor et al., 2011; Balistrieri and Mebane, 2014; Balistrieri and Blank, 2008; Cheng et al., 2005). In addition, it has been used across Europe as part of the Critical Loads approach related to atmospheric deposition and soil pollution by cadmium, lead, mercury and copper (de Vries et al., 2007; Hall et al., 2006; Tipping et al., 2003). Over recent decades, WHAM/Model V was incorporated into the Biotic Ligand Model approach to improve prediction of metal toxicity to aquatic organisms and support the implementation of Environmental Quality Standards (EQS). 
Metal bioavailability and toxicity have long been recognized to be a function of water chemistry (Paquin et al., 2002). Until recently environmental regulations considered only hardnessbased conditions to derive EQS (Beane et al., 2016). However, latest research has increased understanding of the influence of physicochemical variables in metal speciation, and ecotoxicological studies have extended our knowledge of metal effects on biota. Consequently, bioavailability-based approaches such as the Biotic Ligand Models (BLMs) have been implemented within EQS for chemical and ecological assessment, to evaluate the overall quality of a given waterbody (Niyogi and Wood, 2004). In the UK, the BLMs have been simplified to create a user-friendly method known as the Metal Bioavailability Assessment Tool (M-BAT), which use $\mathrm{pH}, \mathrm{DOC}$ and calcium as input data to account for toxicity of single metals in freshwaters within a regulatory context (e.g. Zn-BLM, CU-BLM, Mn-BLM and Ni-BLM) (WFD-UKTAG, 2014; De Schamphelaere and Janssen, 2002; Steenbergen et al., 2005; Lock et al., 2007). The M-BAT tools parameterised to date include those for $\mathrm{Zn}, \mathrm{Cu}, \mathrm{Mn}, \mathrm{Ni}$ and $\mathrm{Pb}$. Some of these tools have been incorporated into a tiered-approach monitoring scheme to implement the bioavailability-based water quality guidelines. However, they have limitations for assessing metal mixture effects since they are based on BLMs for specific metal-organism interactions, and they do not include all dissolved chemical species. To overcome this issue, an alternative bioavailability-based model (WHAM- $\left.F_{T O X}\right)$ developed by Stockdale et al. (2010) offers a plausible option for quantifying mixture toxicity and its potential effects on aquatic organisms. WHAM-Frox, in common with the BLM, uses organisms as reactants. However, WHAM-FTOX assumes that toxicity is related to non-specific binding to organism surfaces rather than specific biotic ligands (Stockdale et al., 2010). Several studies have applied WHAM- $F_{T O X}$ for predicting metal toxicity to aquatic biota in laboratory experiments and linking the effects of chemical speciation of metals and protons to field species richness of freshwater macroinvertebrates (e.g. Ephemeroptera, Plecoptera and Trichoptera (SREPT)) and zooplankton species diversity (Tipping and Lofts, 2013; 2015; Stockdale et al., 2010; 2014; Qiu et al., 2015). 
Despite the scientific and regulatory improvements for the establishment of EQSs, achieving good ecological and chemical status of water bodies according to the Water Framework Directive (WDF) (European Commission, 2000) is still a significant challenge (Environment Agency, 2008a). In the UK, the major impediment to meet this aim is related to diffuse pollution, including metal contamination generated by abandoned mines and mined wastes (Jarvis and Younger, 2000). At a national scale, comprehensive data exist for certain areas but there are substantial gaps for other regions, therefore the assessment of the extent and severity of metal pollution from mining activities is partial (Mayes et al. 2009). As a consequence, the prioritisation of threatened sites to address remediation of metal pollution in a logical and cost-effective manner is a difficult task. River Basin Management Plans (RBMP) provide a good framework for the implementation of mitigation measures. But the application of bioavailability-based standards (EQS-B) offers a significant alternative for the selection of sites at real ecological risk, reducing the burden of remediation targets for efficiently achieving a better quality of water bodies (Environment Agency, 2008b; Harmsen and Naidu, 2013).

This study aims to evaluate differentapproaches used to assess water quality. Focusing on an upland limestone catchment affected by historical mining, we compare hardness based EQS with approaches that consider more detailed water chemistry such as BLM based EQS and WHAM- $F_{T O X}$ Data from a single biological survey were used to give context to the results from the chemical approaches. Additionally, we evaluate the ability of the DGT technique to yield dynamic dissolved concentrations that could be applied to EQS as the WFD allows for water quality criteria to be set based upon dynamic methods incorporating chemical speciation. This contribution complements a companion paper (Valencia-Avellan et al., 2017), which provided an assessment of the geochemical and hydrological processes controlling the main sources of metal pollution. 


\section{Methods}

\subsection{Site description}

The study area is located within the Yorkshire Dales National Park, northern England (Figure 1). Hebden Beck is a headwater catchment (12 km long) containing extensive historical lead and zinc mining operations, which flows through limestone bedrock surrounded by sheep pasture and peat-rich moorland (Jones et al., 2013). Evidence of mining and smelting exists along the length of the river system, from mine tailings and slag to mine water drainage adits and abandoned buildings. A detailed description of the study area is provided in (ValenciaAvellan et al., 2017).

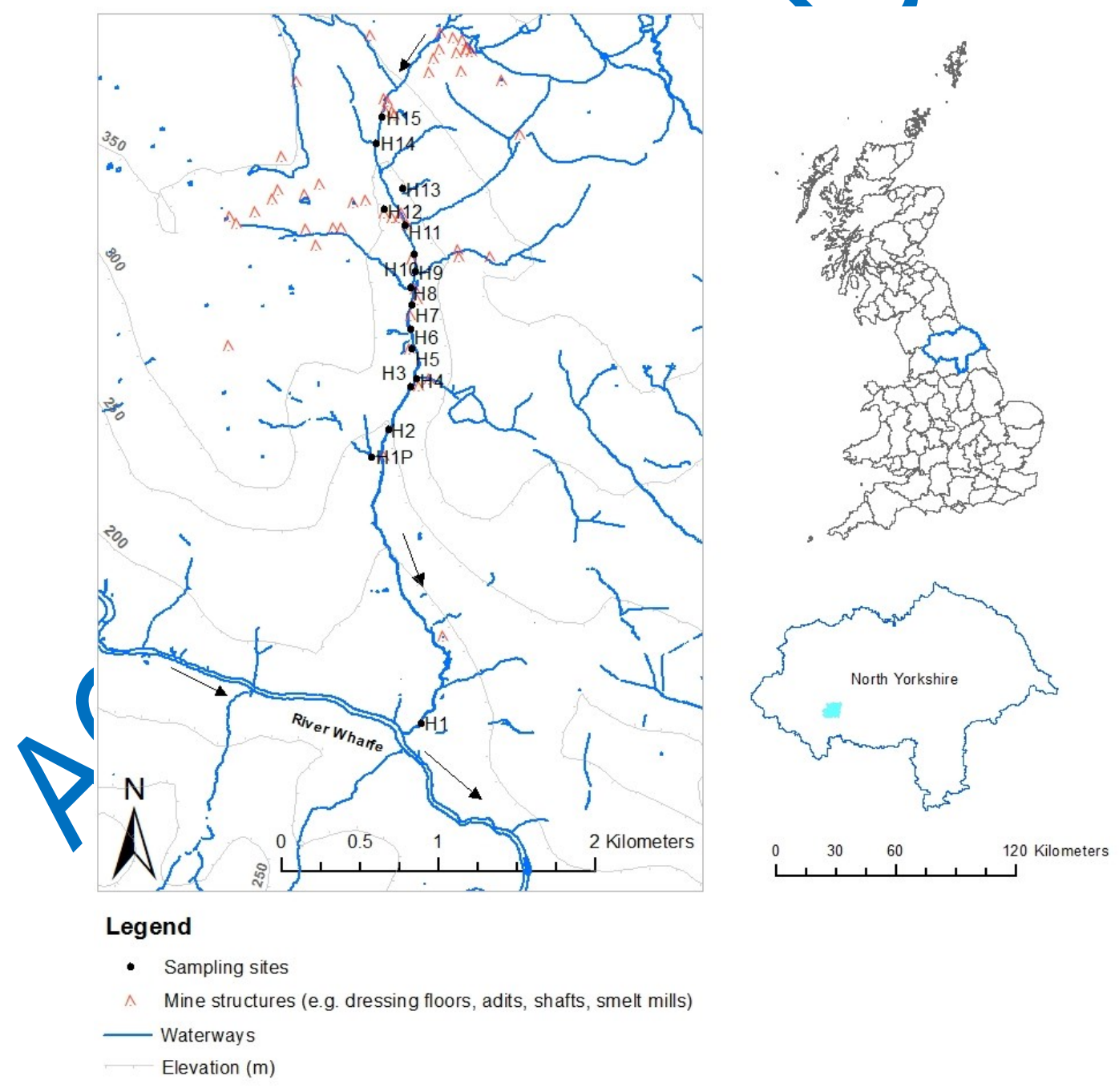


Figure 1. Hebden Beck discharging into the River Wharfe. Black dots represent sampling stations, they are ordered from upper to lower catchment, therefore from $\mathrm{H} 15$ to $\mathrm{H} 1$. Black arrows indicate the direction of flow.

\subsection{Water sampling}

Monthly field surveys were conducted from November 2013 to December 2014 at sixteen sampling sites. Sampling locations (Figure 1) include a source pool, tributaries and the main river channel, covering the most mining impacted area $\left(5 \mathrm{~km}^{2}\right)$. The detailed sampling strategy and analytical procedures are described in Valencia-Avellan et al. (2017). Parameters recorded in situ such as temperature, $\mathrm{pH}$, dissolved oxygen, conductivity and flow, together with measured concentrations of dissolved metals (defined as filterable with a $0.45 \mu \mathrm{m}$ filter) $\left(\mathrm{Zn}^{2+}, \mathrm{Pb}^{2+} \mathrm{Cd}^{2+}\right.$, and $\left.\mathrm{Cu}^{2+}\right)$, major anions $\left(\mathrm{SO}_{4}{ }^{2-}, \mathrm{Cl}^{-}, \mathrm{NO}_{3}^{-}, \mathrm{PO}_{4}^{3-}\right)$ and dissolved inorganic and organic carbon (DIC, DOC) were considered as model input parameters for metal speciation assessment. Concentrations of dissolved metals were also used to evaluate their association with the presence of labile-inorganic species in the river water. Detection limits for metals in water samples were $\mathrm{Zn}: 5.1 \times 10^{-7} \mathrm{~mol} / \mathrm{l}$ and $\mathrm{Pb}: 2.4 \times 10^{-13} \mathrm{~mol} / \mathrm{l}$. For statistical analysis, annual average concentrations were calculated for each site.

\subsection{Determination of $C_{D G T}$ in siver water}

Diffusive Gradients in Thin-films (DGT) devices (DGT Research Ltd, Lancaster, UK) incorporated a Chelex metal binding layer, a $0.8 \mathrm{~mm}$ thick diffusive hydrogel (polyacrylamide gel crossed by agarose cross-linker) and a polyethersulphone filter membrane. DGT devices were subject to minimal handling and transported to and from the site in acid cleaned zip-lock bags. A total of 121 DGT measurements were performed bimonthly from December 2013 to November 2014 across the sampling sites as part of the water sampling surveys. Deployment time averaged approximately one month but varied from 18 days to 43 days. Duplicate devices were deployed at two of the sixteen sites and a field blank was processed in the field once per visit. All DGTs were processed in the laboratory within 24 hours: this involved separating the layers of the probe using acid-washed Teflon tweezers. Each resin gel (Chelex) layer was placed in a $2 \mathrm{ml}$ polypropylene tube with $0.7 \mathrm{ml}$ of $1 \mathrm{M} \mathrm{HNO}_{3}$ (ARISTAR) then stored at $4^{\circ} \mathrm{C}$. 
Immediately before ICPMS analysis, the eluent was diluted 10x with Milli-Q water (18.2 $\mathrm{M} \Omega \cdot \mathrm{cm})$.

Labile metal concentrations were determined following the method of Zhang and Davison (1995). First, the mass of metal (M) in the Chelex resin is calculated (Eq. 1), where $C_{e}$ is the concentration of metals in the $1 \mathrm{M} \mathrm{HNO}_{3}$ elution solution (in $\mu \mathrm{g} / \mathrm{l}$ ) provided by the ICPMS analysis, $V_{g e l}$ is the volume of the resin gel, $V_{H N O 3}$ is the volume of $\mathrm{HNO}_{3}$ added to the resin gel, and $f_{e}$ is the elution factor for each metal, typically 0.8 . Once mass is determined the concentration of labile metals $\left(C_{\mathrm{DGT}}\right)$ can be calculated as per Zhang and Davison (1995) (Eq. 2), where, $M$ is the mass of metal in the Chelex resin, $\Delta g$ is the thickness of the diffusive gel $(0.8 \mathrm{~mm})$ plus the thickness of the filter membrane $(0.13 \mathrm{~mm})$, Dis the diffusion coefficient of metal in the gel reported at http://www.dgtresearch.com/, $t$ is deployment time and $A$ is the exposure area $\left(3.14 \mathrm{~cm}^{2}\right)$.

$M=\left(C_{e}\left(V_{g e l}+V_{H N O 3}\right) / f_{e}\right) / 1000$

$C_{\mathrm{DGT}}=(M \Delta g /(D t A)) / 1000$

\subsection{Speciation modelling using Windermere Humic Aqueous Model (WHAM/Model}

VII)

WHAM/Model VII calculates the chemical speciation of metals using humic $(\mathrm{HA})$ and fulvic acids (FA) as active DOM components. In this study, default model parameters were used together with the measurements for the following inputs; temperature, $\mathrm{pH}$, dissolved anions $\left(\mathrm{Cl}^{-} \mathrm{SO}_{4}^{2-}, \mathrm{NO}_{3}-\right.$ and $\left.\mathrm{PO}_{4}{ }^{3-}\right)$, dissolved metals $\left(\mathrm{Zn}^{2+}, \mathrm{Pb}^{2+}, \mathrm{Cu}^{2+}, \mathrm{Cd}^{2+}, \mathrm{Fe}^{3+}\right.$, and $\left.\mathrm{Al}^{3+}\right)$, dissolved inorganic carbon (DIC; input as carbonate) and DOC. For the modelling DOM was assumed to be composed of $50 \%$ carbon and the active fraction considered to be $65 \%$ fulvic acid, and hence was calculated from DOC values (FA = DOC $\times 1.3)$ (Tipping et al., 2008). The activity of both $\mathrm{Al}$ and $\mathrm{Fe}$ was calculated from the measured total filtered concentration and from the equations derived for Al by Tipping (2005) and for Fe by Lofts and Tipping (2011), with the lower of the two values being adopted. This avoids over-estimation of Al or Fe activity in 
filtrates containing colloidal forms of the metals. Two different scenarios were considered for modelling. Firstly, Al and Fe oxide precipitates were not considered to be active with respect to surface chemistry. In a second scenario it was considered that the oxides contain active binding sites and that one mole of oxide has $90 \mathrm{~g} / \mathrm{mol}$ for Fe (Dzombak and Morel, 1990), and $61 \mathrm{~g} / \mathrm{mol}$ for Al (Lofts, 2012) of active phase. Concentrations of metals bound to oxides were calculated from the output data. These scenarios were applied to allow comparison with the DGT results.

\subsection{Estimating metal mixture toxicity using WHAM-FTOX}

WHAM- $F_{T O X}$, a parameterised version of WHAM established by Stockdale et al. (2010) was applied to evaluate the combined impact of protons $\left(\mathrm{H}^{+}\right)$and metals $\left(\mathrm{Al}^{3+}, \mathrm{Zn}^{2+}, \mathrm{Pb}^{2+}\right.$ and $\left.\mathrm{Cu}^{2+}\right)$. In WHAM- $F_{T O X}$, the metal toxicity function $\left(F_{T O X}\right)$ is considered a product of toxic cation-bound concentrations $(v, \mathrm{mmol} / \mathrm{g})$ and the toxicity coefficient of each analyte $(\alpha)$ and $i$ refers to each toxic cation (Eq. 3).

$F_{T O X}=\Sigma \alpha_{i} v_{i}$

Concentrations of $v_{i}$ were obtained from the WHAM/Model VII modelling as described above without active oxides and with the addition of $10^{-6} \mathrm{~g}$ of colloidal humic acid. Toxicity coefficients for aluminium ( $\left.\alpha_{A \mid}: 2.24\right)$, zinc ( $\left.\alpha_{Z n}: 2.69\right)$, lead ( $\left.\alpha_{\mathrm{Pb}}: 2.51\right)$ and hydrogen $\left(\alpha_{H}: 1\right)$ were adopted from Stockdale etal, (2010). The $\mathrm{Pb}$ toxicity coefficient (with a published $\mathrm{p}$-value of 0.91 ) was used in absence of an alternative published value. We suggest the application of $\alpha_{\mathrm{Pb}}$ with caution as it may be conservative compared with other $\mathrm{Pb}$ toxicity coefficients reported for trout species (cutthroat trout, 6.7; rainbow trout, 4.6) (Tipping and Lofts, 2015).

For these calculations, the following conditions were applied: i) if $F_{\text {TOX }}$ is lower than $2.33\left(F_{\text {TOX- }}\right.$ LT) the maximum $S R_{E P T}$ will be 23 and no toxicity occurs (Eq. 4), ii) a graded linear toxic response occurs as $F_{\text {TOX }}$ increases (Eq. 5), and iii) if $F_{\text {TOX }}$ is higher than 5.20 ( $F_{\text {TOX-UT }}$ ) no species are predicted to be present (Eq. 6). Obtained values were converted to a percentage 
of the maximum $\mathrm{SR}_{\mathrm{EPT}}(90 \%$ percentile). A detailed description of these calculations is provided by Stockdale et al. (2010).

If $F_{\mathrm{TOX}} \leq F_{\mathrm{TOX}-\mathrm{LT}}$, then $\mathrm{SR}_{\mathrm{EPT}}=\mathrm{SR} \mathrm{RPT}_{\mathrm{E} \text { max }}$

If $F_{\mathrm{TOX}}>F_{\mathrm{TOX}-\mathrm{LT}}$, then $\mathrm{SR}_{\mathrm{EPT}}=\mathrm{SR}_{\mathrm{EPT} \text {-max }}-\left(\mathrm{SR}_{\mathrm{EPT} \text {-max }} \times \frac{F_{\mathrm{TOX}}-F_{\mathrm{TOX}-\mathrm{IT}}}{F_{\mathrm{TOX}-\mathrm{UT}}-F_{\mathrm{TOX}-\mathrm{LT}}}\right)$
If $F_{\mathrm{TOX}}>F_{\mathrm{TOX}-U \mathrm{UT}}$, then $\mathrm{SR}_{\mathrm{EPT}}=0$

\subsection{Water quality assessment tools}

Tools with different level of complexity were applied to a consistent set of water chemistry data to assess their contrasting levels of compliance with their respective standards.Firstly, water hardness was calculated at each sampling point for applying established metal limits under hardness-based standards (Environment Agency, 2011). For the hardness based values a risk characterization ratio (RCR) was estimated dividing the dissolved metal concentrations or Predicted Effect Concentration (PEC) by the calculated hardness-based limits or No Predicted Effect Concentrations (PNEC). Water quality standards were exceeded (i.e., over accepted limits $)$ if $R C R \geq 1(R C R=P E C / P N E C)$.

Secondly, assessment tools based on the BLM were applied. One tool, known as the Metal Bioavailability Assessment Tool (M-BAT) was used for $\mathrm{Zn}$ (and is also parameterised for $\mathrm{Cu}$, $\mathrm{Mn}$ and $\mathrm{Ni}$ ) and the "Final Pb Screening Tool" was used for $\mathrm{Pb}$, these are both available from the UK Water Framework Directive Technical Advisory Group (WFD-UKTAG, 2014). An additional $\mathrm{Pb}$ tool is also available from the International Lead Association that combines bioavailability models with detailed species sensitivity distribution (SSD) analyses (International Lead Association, 2017). These two $\mathrm{Pb}$ tools are referred to as $\mathrm{Pb}-\mathrm{FST}$ and $\mathrm{Pb}$ SSD for the UK-TAG and ILA versions, respectively. For these BLM based tools, an alternate risk characterisation ratio $(R C R)$ was calculated, where PEC values are the bioavailable metals based on dissolved concentrations, and PNEC are the site-specific values obtained from the tools, if RCR $\geq 1$ water quality standards were exceeded (Merrington and Peters, 2013; WFD-UKTAG, 2014). For these calculations, Zn-BAT considered dissolved 
concentrations and the water chemical parameters $\mathrm{Ca}^{2+}, \mathrm{pH}$ and $\mathrm{DOC}$ as input data, $\mathrm{Pb}-\mathrm{FST}$ only required concentrations for $\mathrm{Pb}$ and $\mathrm{DOC}$. In the case of the $\mathrm{Pb}-\mathrm{SSD}$, it required additional parameters such as $\mathrm{Mg}^{2+}, \mathrm{Na}^{+}, \mathrm{K}^{+}, \mathrm{SO}_{4}{ }^{2-}, \mathrm{Cl}^{-}, \mathrm{CO}_{3}{ }^{2-}$. Thirdly, the model WHAM-FTox derived from WHAM/Model VII was applied to predict the effect of water chemistry on the maximum species richness $\left(\mathrm{SR}_{\mathrm{EPT} \text {-max }}\right)$ as described above.

\subsection{Biological survey}

A single macroinvertebrate survey was carried out at all sites in August 2014. Samples were collected using a standard kick sampling technique and modified from the Water Framework Directive compliant methodologies (EU-STAR project, 2004). Given the small size of watercourses in the survey, one-minute kick samples were taken at thifteen sites, 30 second kick samples were taken at 2 narrow sites and one sweep sample was taken in a pond at the top of the catchment. Kick samples were followed by a stone search to collect organisms attached to the substrate. Specimens were analysed /ive at each site. Several were preserved and taken back to the lab for identification confirmation. Invertebrates were analysed to family level. All relevant families within the sample were scored on a presence or absence basis and frequency scale, using the Blological Monitoring Working Party (BMWP) index which rates invertebrates based on thein tolerance to organic pollution. BMWPs greater than 100 are associated with unpolluted streams, while the scores of heavily polluted streams are less than 10. In addition, the average sensitivity of the macroinvertebrate families known as the Average Score Per Taxon (ASPT) was determined by dividing the BMWP scores by the number of taxa present. Scores for ASPT are considered from 0 to 10, where 10 indicates a unpolluted site containing large numbers of high scoring taxa (Armitage et al., 1983) (Table 1). Impacts of metal pollution might not be reflected by the BMWP and associated average score per taxon (ASPT) scoring systems as they were originally developed as indicators of organic pollution (Tipping et al., 2009). Despite this caveat, BMWP scores, number of taxa and ASPT values were compared with metal concentrations and outcomes from water quality assessment tools. 
Table 1. Scale of water quality categories based on BMWP and ASPT scores.

\begin{tabular}{cccl}
\hline BMWP score & ASPT score & Water Category & Interpretation \\
\hline $0-10$ & & Very poor & Heavily polluted \\
$11-40$ & $<4$ & Poor & Polluted or impacted \\
$41-70$ & $>4$ & Moderate & Moderately impacted \\
$71-100$ & $>5$ & Good & Clean but slightly impacted \\
$>100$ & $>6$ & Very good & Unpolluted, un-impacted \\
\hline
\end{tabular}

\section{Results}

General water chemistry for Hebden Beck has been reported in detail by Valencia-Avellan et al. (2017). It is dominated by the underlying geology of the catchment (i.e. buffered with high $\mathrm{Ca}$ and circumneutral $\mathrm{pH}$ values), whilst metal levels are associated with the weathering and erosion of $\mathrm{Pb}$ and $\mathrm{Zn}$ minerals exposed by past mining. Mine-impacted water is characterised by circumneutral $\mathrm{pH}(6.3-7.5)$ and elevated metal concentrations. Maximum concentrations of $\mathrm{Pb}, \mathrm{Cd}, \mathrm{Zn}$, and $\mathrm{Cu}$ were measured in site $\mathrm{H} 12$ corresponding to an ephemeral tributary flowing through spoil mine wastes $4.4 \times 10^{-6}, 4.18 \times 10^{-7}, 6.5 \times 10^{-5}, 3.12 \times 10^{-7} \mathrm{~mol} / \mathrm{l}$, respectively) (Table S1). Full chemistry data are included in Tables S1-S3. Considering the significantly higher concentrations of $\mathrm{Zn}$ and $\mathrm{Pb}$, we focus primarily on these metals. Associations between DIC/DOC, sulfate and metals were identified. DIC was strongly correlated with Ca and $\mathrm{Mg}\left(\mathrm{R}^{2}=0.9\right)$, whilst DOC was more closely correlated with levels of $\mathrm{Fe}, \mathrm{Al}, \mathrm{Pb}$ and $\mathrm{Cu}(0.1 \geq \mathrm{r} \leq 0.7)$. Sulfate correlated strongly with $\mathrm{Zn}$ and $\mathrm{Cd}\left(\mathrm{R}^{2}=0.6,0.7 ; \mathrm{p}\right.$ $<0.001$ ), possibly associated with the dissolution of sulfide minerals (Table S4).

\subsection{Dynamic metal $\left(C_{D G T}\right)$ concentrations}

From DGT measurements at each site, annual average $\mathrm{Zn}-C_{\mathrm{DG}}$ concentrations ranged from $2.8 \times 10^{-5}$ to $4.8 \times 10^{-9} \mathrm{~mol} / \mathrm{l}$ and for Pb- $C_{\mathrm{DGT}}$ from $1.1 \times 10^{-7}$ to $1.1 \times 10^{-10} \mathrm{~mol} / \mathrm{l}$. Highest $\mathrm{Zn}$ $C_{\text {DGT }}$ identified in perennial tributaries were $\mathrm{H} 7: 2.8 \times 10^{-5} \mathrm{Zn} \mathrm{mol} / \mathrm{l}$ and highest $\mathrm{Pb}-\mathrm{C}_{\mathrm{DGT}}$ in 
ephemeral tributaries $\mathrm{H} 13$ and $\mathrm{H} 12: 1.1 \times 10^{-7} \mathrm{~Pb}$ mol/l, while in main channel maximum concentrations were observed in $\mathrm{H} 6: 7.5 \times 10^{-6} \mathrm{Zn} \mathrm{mol} / \mathrm{l}$ and $\mathrm{H} 10: 2.3 \times 10^{-8} \mathrm{~Pb} \mathrm{~mol} / \mathrm{l}$ (Table 2).

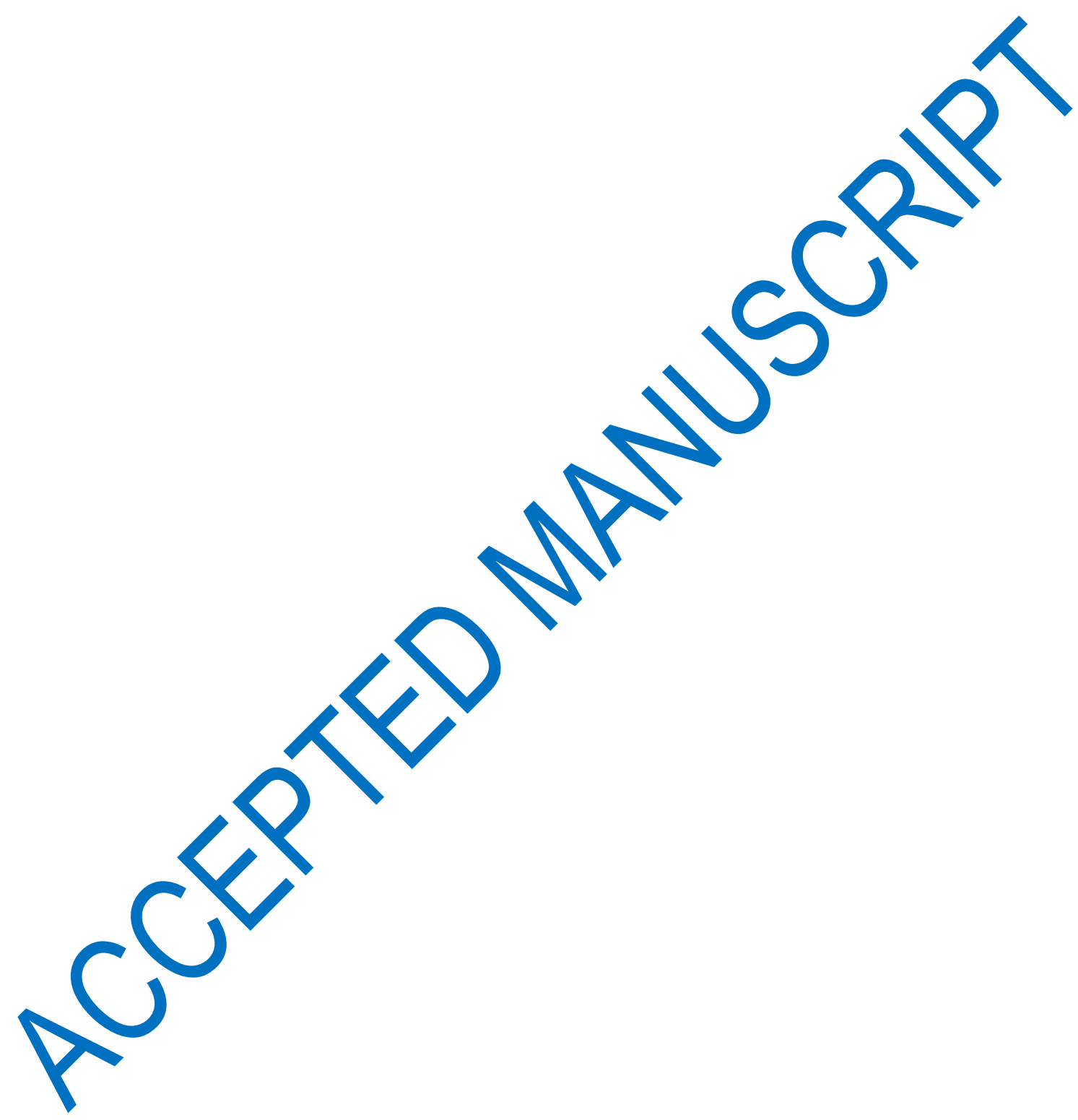




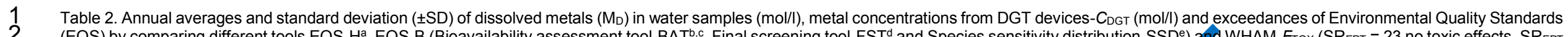
(EQS) by comparing different toolsEQS-Ha', EQS-B (Biסav Ratio, PEC: Predicted Effect Concen Description of sites are indicated as reservoir (RS), main channel (MC), ephemeral tributaries (ET) and perennial tributaries (PT).

\begin{tabular}{|c|c|c|c|c|c|c|c|c|c|c|c|c|}
\hline \multirow{2}{*}{ Sites } & \multirow{2}{*}{ Description } & \multirow{2}{*}{$\begin{array}{c}\mathrm{Zn}_{\mathrm{D}^{-}} \\
\text {measured } \\
(\mathrm{mol} / \mathrm{l})\end{array}$} & \multirow{2}{*}{$\begin{array}{c}\mathrm{Zn}-C_{\mathrm{DGT}} \\
(\mathrm{mol} /)\end{array}$} & \multicolumn{2}{|c|}{ Zn RCR } & \multirow{2}{*}{$\begin{array}{c}\mathrm{Pb}_{\mathrm{D}^{-}} \\
\text {measured } \\
(\mathrm{mol} / \mathrm{l})\end{array}$} & \multirow{2}{*}{$\begin{array}{l}\mathrm{Pb}-\mathrm{C}_{\mathrm{DGT}} \\
(\mathrm{mol} / \mathrm{l})\end{array}$} & \multicolumn{3}{|c|}{$\mathrm{Pb}$ RCR } & \multicolumn{2}{|c|}{ WHAM- $F_{\text {TOX }}$} \\
\hline & & & & $E Q S-H$ & $E Q S-B$ & & & E & $-B(F S T$ & $E Q S-B(S S D)$ & $S_{R_{E P T}}$ & $\% S R_{\text {EPT }}$ \\
\hline $\mathrm{H} 15$ & RS & $\begin{array}{c}3.1 \times 10^{-5} \\
\left( \pm 7.2 \times 10^{-6}\right)\end{array}$ & $\begin{array}{c}1.2 \times 10^{-5} \\
\left( \pm 6.9 \times 10^{-6}\right)\end{array}$ & 253.5 & 54.0 & $\begin{array}{c}1.3 \times 10^{-6} \\
\left( \pm 4.0 \times 10^{-7}\right)\end{array}$ & $\begin{array}{c}5.7 \times 10^{-8} \\
\left( \pm 5.2 \times 10^{-8}\right)\end{array}$ & & & 8.5 & 10 & 43 \\
\hline $\mathrm{H} 14$ & PT & $\begin{array}{c}2.1 \times 10^{-5} \\
\left( \pm 5.2 \times 10^{-6}\right)\end{array}$ & $\begin{array}{c}1.5 \times 10^{-5} \\
\left( \pm 4.4 \times 10^{-6}\right)\end{array}$ & 174.7 & 45.9 & $\begin{array}{c}7.6 \times 10^{-7} \\
\left( \pm 3.6 \times 10^{-7}\right)\end{array}$ & $\begin{array}{c}6.1 \times 10^{-8} \\
\left( \pm 1.9 \times 10^{-8}\right) \\
\end{array}$ & & $15.8^{d}$ & 6.8 & 13 & 55 \\
\hline $\mathrm{H} 13$ & ET & $\begin{array}{c}3.2 \times 10^{-6} \\
\left( \pm 6.3 \times 10^{-6}\right) \\
\end{array}$ & $\begin{array}{c}6.1 \times 10^{-7} \\
\left( \pm 3.2 \times 10^{-7}\right) \\
\end{array}$ & 25.9 & $4.1^{b}$ & $\begin{array}{c}9.9 \times 10^{-7} \\
\left( \pm 2.6 \times 10^{-7}\right) \\
\end{array}$ & $\begin{array}{c}1.1 \times 10^{-7} \\
\left( \pm 6.6 \times 10^{-8}\right) \\
\end{array}$ & & $10.2^{d}$ & $1.1^{\mathrm{e}}$ & 9 & 38 \\
\hline $\mathrm{H} 12$ & ET & $\begin{array}{c}6.5 \times 10^{-5} \\
\left( \pm 3.0 \times 10^{-5}\right) \\
\end{array}$ & $\begin{array}{c}2.7 \times 10^{-5} \\
\left( \pm 4.0 \times 10^{-6}\right)\end{array}$ & 85.0 & 117.6 & $\begin{array}{c}1.4 \times 10^{-6} \\
\left( \pm 4.4 \times 10^{-7}\right) \\
\end{array}$ & & 39.5 & $35.0^{d}$ & 17.1 & 15 & 66 \\
\hline $\mathrm{H} 11$ & PT & $\begin{array}{c}6.3 \times 10^{-6} \\
\left( \pm 2.1 \times 10^{-5}\right) \\
\end{array}$ & $\begin{array}{c}3.3 \times 10^{-6} \\
\left( \pm 7.6 \times 10^{-6}\right) \\
\end{array}$ & 51.3 & 8.7 & $\begin{array}{c}1.5 \times 10^{-7} \\
\left( \pm 4.5 \times 10^{-7}\right) \\
\end{array}$ & $\begin{array}{r}9.2 \times 10^{-9} \\
\left( \pm 1.8 \times 10^{-8}\right)\end{array}$ & 4.4 & $1.6^{d}$ & 0.8 & 20 & 85 \\
\hline $\mathrm{H} 10$ & MC & $\begin{array}{c}6.8 \times 10^{-6} \\
\left( \pm 2.8 \times 10^{-6}\right) \\
\end{array}$ & $\begin{array}{c}5.2 \times 10^{-6} \\
\left( \pm 2.5 \times 10^{-6}\right) \\
\end{array}$ & 55.6 & 11.1 & $\begin{array}{r}3.8 \times 10^{-7} \\
\left( \pm 2.0 \times 10^{-7}\right) \\
\end{array}$ & $\begin{array}{r}2.3 \times 10^{-8} \\
\left( \pm 1.5 \times 10^{-8}\right) \\
\end{array}$ & 11.2 & $6.5^{d}$ & 2.9 & 19 & 82 \\
\hline H9 & PT & $\begin{array}{c}1.5 \times 10^{-6} \\
\left( \pm 1.9 \times 10^{-6}\right) \\
\end{array}$ & $\begin{array}{c}1.3 \times 10^{-6} \\
\left( \pm 5.5 \times 10^{-7}\right)\end{array}$ & 12.0 & $2.1^{b}$ & $10 \times 10^{-7}$ & $\begin{array}{c}4.6 \times 10^{-9} \\
\left( \pm 4.4 \times 10^{-9}\right)\end{array}$ & 2.9 & $1.0^{d}$ & 0.5 & 18 & 77 \\
\hline $\mathrm{H} 8$ & PT & $\begin{array}{c}4.1 \times 10^{-6} \\
\left( \pm 1.5 \times 10^{-6}\right) \\
\end{array}$ & $\begin{array}{c}3.9 \times 10^{-6} \\
\left( \pm 2.3 \times 10^{-6}\right) \\
\end{array}$ & 3.6 & 7.4 & & $\begin{array}{c}1.1 \times 10^{-8} \\
\left( \pm 1.1 \times 10^{-8}\right) \\
\end{array}$ & 2.6 & $2.0^{d}$ & 1.1 & 23 & 100 \\
\hline $\mathrm{H} 7$ & PT & $\begin{array}{c}4.9 \times 10^{-5} \\
\left( \pm 1.3 \times 10^{-5}\right) \\
\end{array}$ & $\begin{array}{c}2.8 \times 10^{-5} \\
\left( \pm 8.5 \times 10^{-6}\right) \\
\end{array}$ & 42.9 & & $\begin{array}{r}2.1 \times 10^{-8} \\
\left( \pm 6.1 \times 10^{-8}\right) \\
\end{array}$ & $\begin{array}{c}1.2 \times 10^{-9} \\
\left( \pm 1.1 \times 10^{-9}\right) \\
\end{array}$ & 0.6 & $3.0^{d}$ & 1.7 & 18 & 76 \\
\hline $\mathrm{H} 6$ & $\mathrm{MC}$ & $\begin{array}{c}7.8 \times 10^{-6} \\
\left( \pm 1.5 \times 10^{-6}\right)\end{array}$ & $\begin{array}{c}7.5 \times 10^{-} \\
{ }^{6}\left( \pm 1.0 \times 10^{-6}\right)\end{array}$ & 10.2 & & $\begin{array}{c}2.4 \times 10^{-7} \\
\left( \pm 9.9 \times 10^{-8}\right)\end{array}$ & $\begin{array}{c}8.5 \times 10^{-9} \\
\left( \pm 4.4 \times 10^{-9}\right) \\
\end{array}$ & 6.9 & $3.8^{d}$ & 1.7 & 20 & 88 \\
\hline H5 & PT & $\begin{array}{c}1.3 \times 10^{-5} \\
\left( \pm 2.9 \times 10^{-6}\right) \\
\end{array}$ & $\begin{array}{c}1.3 \times 10^{-5} \\
\left( \pm 1.5 \times 10^{-6}\right)\end{array}$ & & & $\begin{array}{c}2.6 \times 10^{-7} \\
\left( \pm 2.2 \times 10^{-7}\right)\end{array}$ & $\begin{array}{c}4.9 \times 10^{-8} \\
\left( \pm 1.8 \times 10^{-8}\right)\end{array}$ & 7.5 & $14.6^{d}$ & 8.7 & 23 & 100 \\
\hline $\mathrm{H} 4$ & ET & $\begin{array}{c}5.5 \times 10^{-7} \\
\left( \pm 1.4 \times 10^{-7}\right) \\
\end{array}$ & $\begin{array}{c}2.6 \times 10^{-7} \\
\left( \pm 8.9 \times 10^{-8}\right) \\
\end{array}$ & & & $\begin{array}{c}2.1 \times 10^{-8} \\
\left( \pm 8.2 \times 10^{-9}\right)\end{array}$ & $\begin{array}{c}3.7 \times 10^{-9} \\
\left( \pm 5.4 \times 10^{-10}\right) \\
\end{array}$ & 0.6 & 0.4 & $0.02 \mathrm{e}$ & 8 & 35 \\
\hline H3 & PT & $<5.1 \times 10^{-7}$ & $\begin{array}{r}1.2 \times 10^{-6} \\
\left( \pm 5.1 \times 10^{-8}\right) \\
\end{array}$ & & 0.8 & $\begin{array}{c}8.0 \times 10^{-10} \\
\left( \pm 9.5 \times 10^{-10}\right)\end{array}$ & $\begin{array}{c}5.4 \times 10^{-10} \\
\left( \pm 4.1 \times 10^{-10}\right)\end{array}$ & 0.02 & 0.1 & 0.1 & 23 & 100 \\
\hline $\mathrm{H} 2$ & $\mathrm{MC}$ & $\begin{array}{c}7.4 \times 10^{-6} \\
\left( \pm 1.1 \times 10^{-6}\right) \\
\end{array}$ & $\begin{array}{r}7.0 \times 10^{6} \\
\left( \pm 1.0 \times 10^{-6}\right) \\
\end{array}$ & a) 7 & 17.7 & $\begin{array}{c}1.9 \times 10^{-7} \\
\left( \pm 1.4 \times 10^{-7}\right) \\
\end{array}$ & $\begin{array}{c}1.3 \times 10^{-8} \\
\left( \pm 3.9 \times 10^{-9}\right)\end{array}$ & 5.5 & $4.4^{d}$ & 2.3 & 22 & 97 \\
\hline $\mathrm{H} 1 \mathrm{P}$ & PT & $\begin{array}{c}5.6 \times 10^{-7} \\
\left( \pm 1.1 \times 10^{-6}\right)\end{array}$ & $\begin{array}{r}4.8 \times 10^{-9} \\
\left( \pm 4.5 \times 10^{-9}\right) \\
\end{array}$ & 0.7 & 2.4 & $\begin{array}{c}3.5 \times 10^{-9} \\
\left( \pm 3.1 \times 10^{-9}\right) \\
\end{array}$ & $\begin{array}{c}1.1 \times 10^{-10} \\
\left( \pm 3.0 \times 10^{-11}\right)\end{array}$ & 0.3 & 0.2 & 0.1 & 23 & 100 \\
\hline $\mathrm{H} 1$ & $\mathrm{MC}$ & $\begin{array}{c}2.4 \times 10^{-6} \\
\left( \pm 1.1 \times 10^{-6}\right)\end{array}$ & $\begin{array}{c}2.5 \times 10^{-6} \\
\left( \pm 6.6 \times 10^{-7}\right)\end{array}$ & 2.1 & 4.2 & $\begin{array}{c}8.0 \times 10^{-8} \\
\left( \pm 6.6 \times 10^{-8}\right)\end{array}$ & $\begin{array}{c}3.7 \times 10^{-9} \\
\left( \pm 3.3 \times 10^{-9}\right)\end{array}$ & 2.3 & $1.8^{d}$ & 1.0 & 23 & 100 \\
\hline
\end{tabular}

a Limits of EQS based on site-specific hardness, $\mathrm{Zn}$ EOS- $\mathrm{H}=1.3 \times 10^{-7}$ (for sites $\left.\mathrm{H} 15, \mathrm{H} 14, \mathrm{H} 13, \mathrm{H} 11, \mathrm{H} 10, \mathrm{H} 9, \mathrm{H} 4\right) ; 7.6 \times 10^{-7}$ (for sites $\mathrm{H} 12, \mathrm{H} 6, \mathrm{H} 2, \mathrm{H} 1 \mathrm{P}$ ) and $1.2 \times 10^{-6}$ (for sites $\mathrm{H} 8, \mathrm{H} 7, \mathrm{H} 5, \mathrm{H} 3, \mathrm{H} 1$ ). $\mathrm{Pb} \mathrm{EQS}-\mathrm{H}=3.5 \times 10^{-8}$ for all sites . DH=6) was applied for Zn EQS-B calculations.

d Measured $\mathrm{Pb}$ exceds outside the limits of Zn-BAT tool. Defaul im

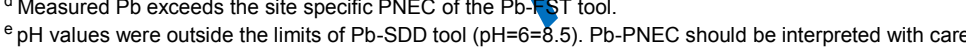


DGT measurements were compared with the mean of metal concentrations in water samples calculated from samples taken at both the deployment and retrieval dates. Figure 2 shows the linear correlations between measured dissolved metals in water samples and metals measured by DGT (M-C $\left.C_{D G T}\right)$. A strong relationship exists between $\mathrm{Zn}$ measured dissolved species and $\mathrm{Zn}-C_{\mathrm{DGT}}\left(\mathrm{R}^{2}=0.75, \mathrm{p}<0.001\right)$. For $\mathrm{Pb}$, a moderate relationship was observed between dissolved concentrations and $C_{D G T}\left(R^{2}=0.59, p<0.001\right)$. Whilst there is correlation between $C_{D G T}$ and dissolved concentrations there is a lesser degreenof agrement, as indicated by the slopes of $0.46(\mathrm{Zn})$ and $0.07(\mathrm{~Pb})$ (Figure 2).
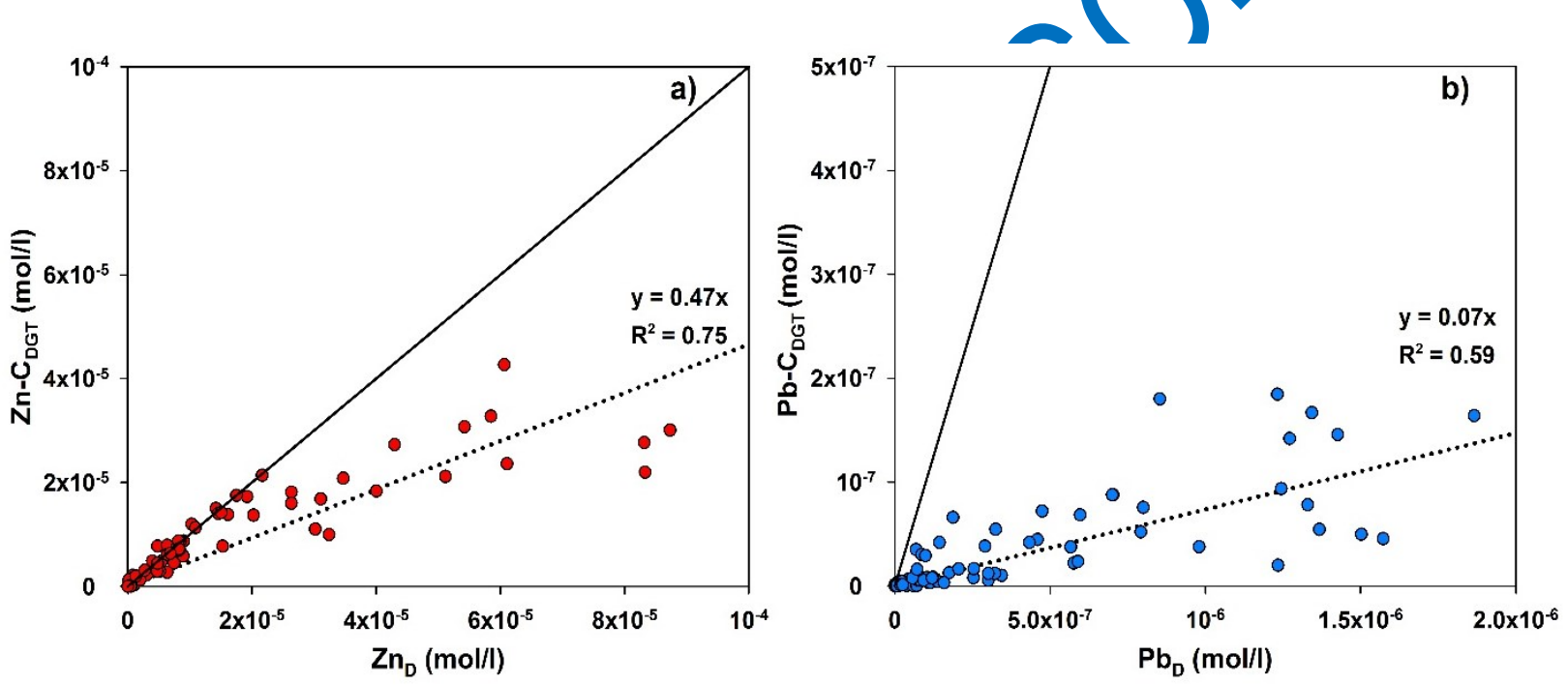

Figure 2. Measured dissolved metals versus DGT concentrations $\left(C_{D G T}\right)$. Panel a, shows the correlation between $\mathrm{Zn}_{D}$ and $\mathrm{Zn}$-CDGT. Panel $\mathrm{b}$, shows the correlation of $\mathrm{Pb}_{D}$ with $\mathrm{Pb}-\mathrm{C}_{\text {DGT }}$. Dotted lines represent a regression line, solid lines represent the ideal 1:1 line.

\subsection{Metal speciation calculated by WHAM/Model VII}

3.3.1. Modelling where oxide precipitates are not surface active

Concentrations of predicted organic and inorganic species of $\mathrm{Zn}$, and $\mathrm{Pb}$ are shown in Figure

3. Average concentrations of metal-organic complexes (i.e. metal-fulvic acid (FA) complexes) were higher for $\mathrm{Zn}$ than $\mathrm{Pb}$, although as a function of total dissolved metal, $\mathrm{Pb}$ had a greater fraction present as organic complexes, consistent with a higher $\mathrm{Pb}-\mathrm{FA}$ model binding constant.

Values of organic species ranged for $\mathrm{Zn}$ from $2.9 \times 10^{-8}$ to $1.2 \times 10^{-5} \mathrm{~mol} / \mathrm{l}$ and for $\mathrm{Pb}$ from 2.0 
$\times 10^{-10}$ to $1.1 \times 10^{-6} \mathrm{~mol} / \mathrm{l}$, where site $\mathrm{H} 15$ presented the highest concentrations for both metals.

For inorganic species, higher average concentrations occurred for $\operatorname{Zn~}\left(3.6 \times 10^{-7}\right.$ to $5.8 \times 10^{-5}$ $\mathrm{mol} / \mathrm{l})$, and lower for $\mathrm{Pb}\left(6.0 \times 10^{-10}\right.$ to $\left.7.2 \times 10^{-7} \mathrm{~mol} / \mathrm{l}\right)$, with the highest concentrations in sites $\mathrm{H} 12$ and $\mathrm{H} 13$, respectively. Figures $4 \mathrm{a}$ and $4 \mathrm{c}$ show linear correlation between dissolved inorganic metal species predicted by WHAM and $C_{D G T}$ measurements of $\mathrm{Zn}$ and $\mathrm{Pb}$. Good correspondence was observed for $\mathrm{Zn}\left(\mathrm{R}^{2}=0.81, p<0.001\right)$ and moderate relationship for $\mathrm{Pb}$ $\left(R^{2}=0.54, p<0.001\right)$

\subsubsection{Modelling where oxide precipitates are surface reactive}

Precipitation of $\mathrm{Fe}$ and $\mathrm{Al}$ oxides (with reactive surface) were simulated by using the concentration of precipitated metal to the mass of active phase (Figures $4 \mathrm{~b}$ and $4 \mathrm{~d}$ ). Similar correlations were obtained when oxides were not surface reactive $\left(R^{2}=0.81, R^{2}=0.51\right)$. The presence of colloidal $\mathrm{Pb}$ was estimated showing more affinity to FeOx than AlOx. Concentrations of $\mathrm{Pb}-\mathrm{FeO}$ complexes ranged from $5.7 \times 10^{-11}$ to $2.5 \times 10^{-7} \mathrm{~mol} / \mathrm{l}$, while $\mathrm{Pb}-$ AlOx complexes from $6.8 \times 10^{-12}$ to $2.5 \times 10^{-8} \mathrm{~mol} / \mathrm{l}$. For both complexes the highest concentrations were identified in $\mathrm{H} 12$ (Figure 5).

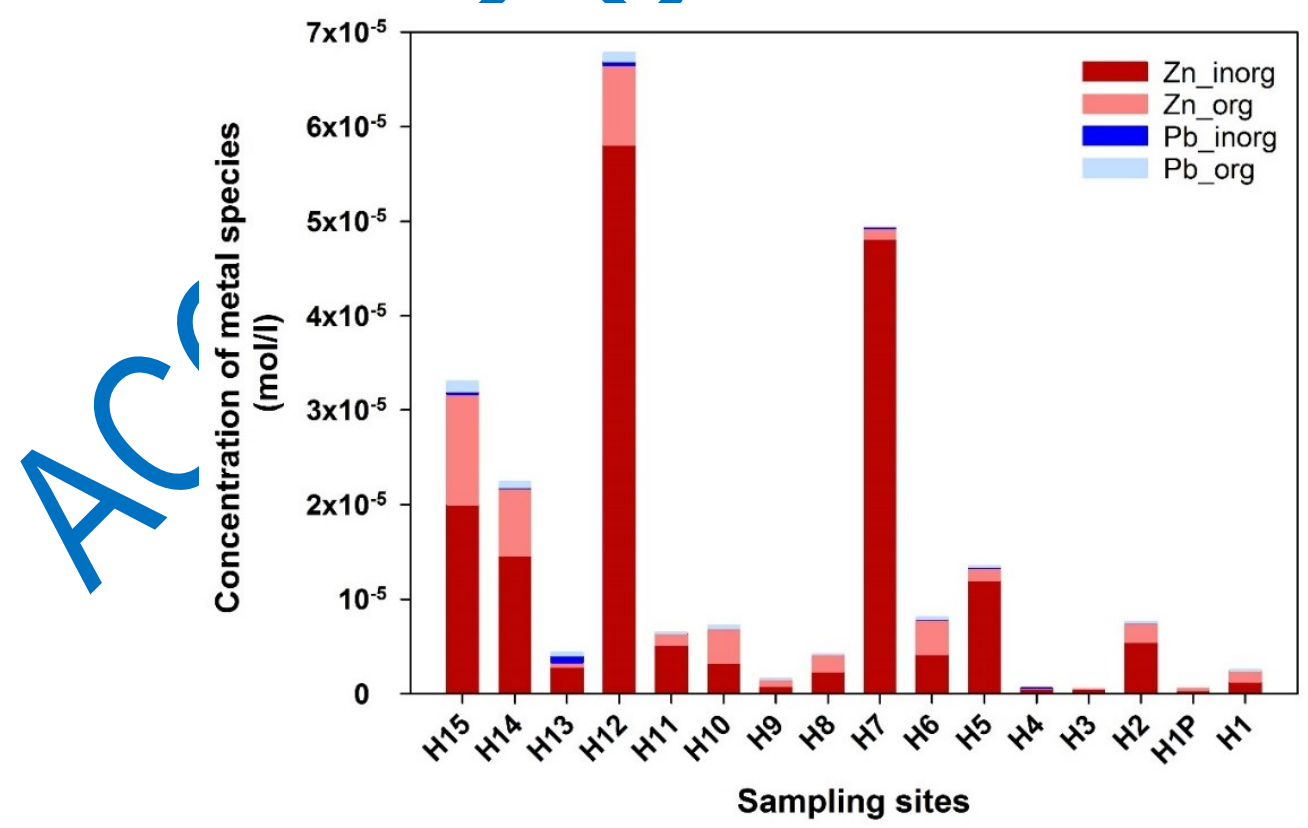

47 Figure 3. Calculated concentrations of metal species in the absence of surface active oxide precipitates 48 using WHAM/Model VII. 

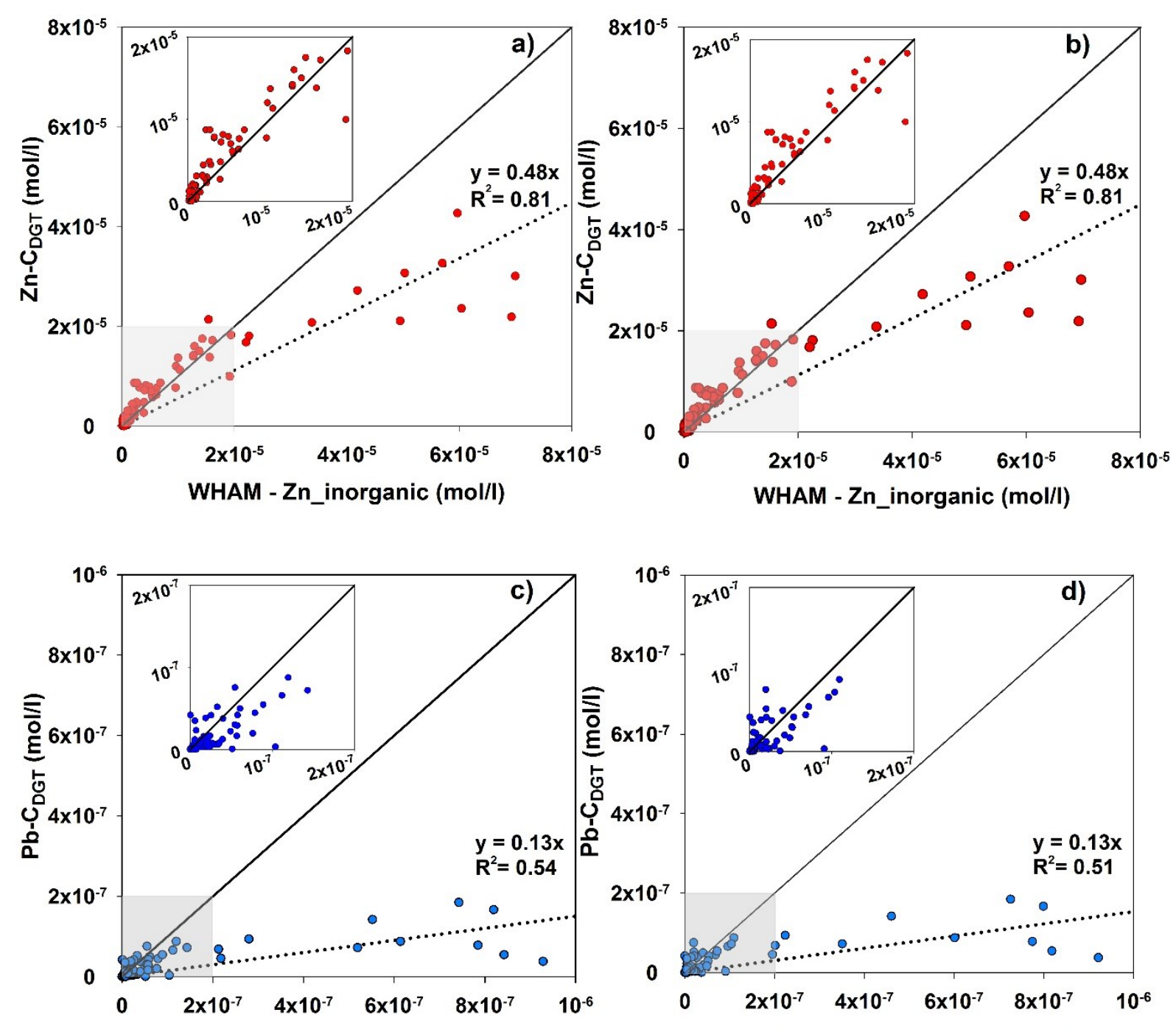

WHAM - Pb_inorganic (mol/l)

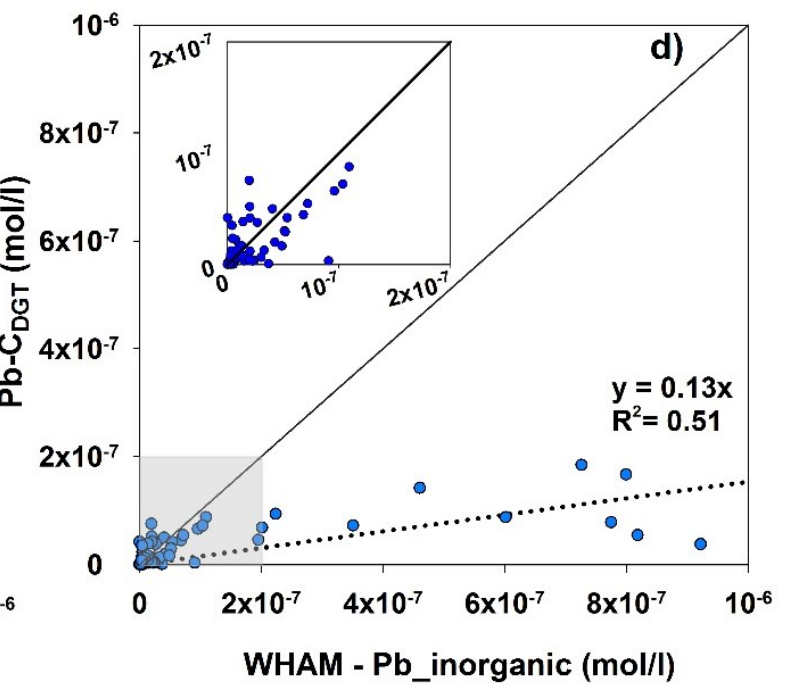

Figure 4. Relationship between inorganic metal concentrations (mol/l) calculated by WHAM and metal concentrations from CDGs measurements (mol/l) for $\mathrm{Zn}$ (panels a and $\mathrm{b}$ ) and $\mathrm{Pb}$ (panels $\mathrm{c}$ and $\mathrm{d}$ ). Inorganic concentrations were predicted in WHAM in the absence (panels a and c) and presence (panels $b$ and d) of active oxides. Dotted lines represent a regression line and solid lines represent the ideal 1:1 line

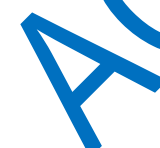




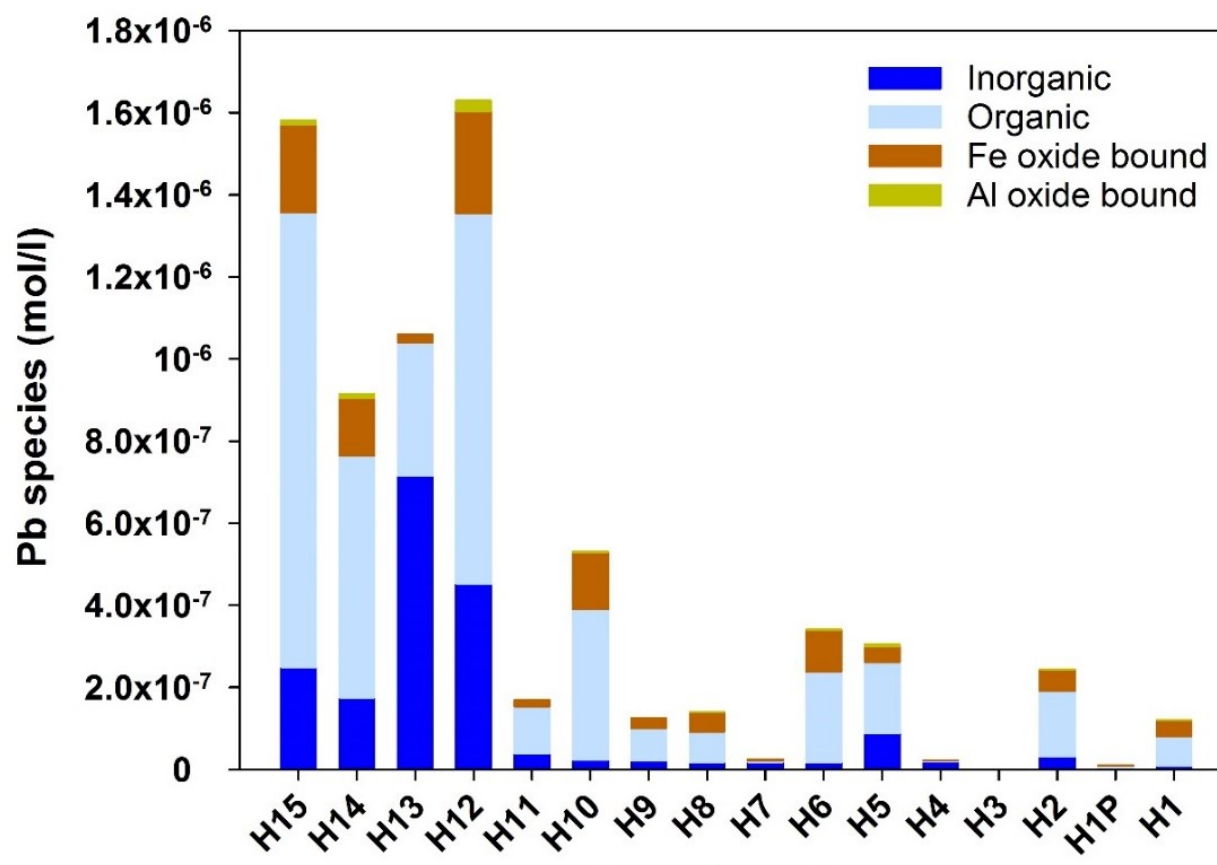

Sampling sites

Figure 5. Calculated concentrations of $\mathrm{Pb}$ species in the presence of surface active oxide precipitates using WHAM/Model VII.

\subsection{Water quality and ecotoxicological assessment}

\subsubsection{Environmental Quality StandardS EQS-H and EQS-B}

Annual averages concentrations were used for assessing EQS-H and EQS-B. The EQS-H standards were exceeded for Zn from 0.2 to 254 -fold and for $\mathrm{Pb}$ from 0.02 to 40 -fold (Table 2). Highest $\mathrm{Zn}$ exceedances ( $>60$-fold) occurred in upstream sites surrounded by spoil mine wastes $(\mathrm{H} 15, \mathrm{H} 14$ and $\mathrm{H} 12)$. These sites and $\mathrm{H} 13$, also presented highest $\mathrm{Pb}$ exceedances (> 20-fold). The EQS-B standards were exceeded for $\mathrm{Zn}$ from 0.8 to 209 -fold and for $\mathrm{Pb}$ from 0.02 to 17 -fold. Highest $\mathrm{Zn}$ exceedances (> 50-fold) appeared in sites $\mathrm{H} 7>\mathrm{H} 12>\mathrm{H} 15$ which represent a mine adit, an ephemeral tributary flowing through spoil mine wastes and a reservoir next to a smelting mill. For $\mathrm{Pb}$, highest levels (> 6-fold) were present in $\mathrm{H} 12>\mathrm{H} 5$, H15 > H14 (Table 2).

\subsubsection{Toxicity function: WHAM-FTox}

WHAM- $F_{\text {TOx }}$ considers humic acid (HA) bound to be a plausible proxy for organism bound metal. Concentrations of metals bound to humic acid ranged for $\mathrm{Zn}(0.0013$ to $0.9 \mathrm{mmol} / \mathrm{g})$ 
and $\mathrm{Pb}(0.0001$ to $0.09 \mathrm{mmol} / \mathrm{g})$ (Figure 6). Reservoir $(\mathrm{H} 15)$, perennial tributaries $(\mathrm{H} 14, \mathrm{H} 7)$ and ephemeral tributary $(\mathrm{H} 12)$ were characterised by high $\mathrm{Zn}$ concentrations $(\geq 0.5 \mathrm{mmol} / \mathrm{g})$, the same sites (except for $\mathrm{H} 7$ ) presented high $\mathrm{Pb}$ concentrations $(\geq 0.05 \mathrm{mmol} / \mathrm{g}$ ).

84

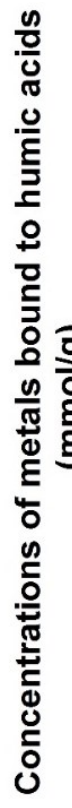

Figure 6. Calculated concentrations of $\mathrm{Zn}$ and $\mathrm{Pb}$ bound to humic acids (mmol/g).

\section{Sampling sites}

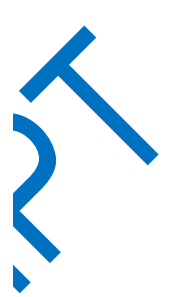

0.

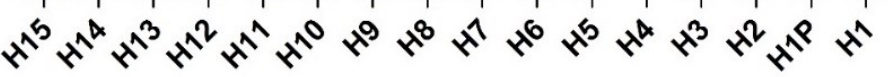

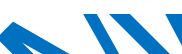


Table 3. Predicted species richness of macroinvertebrates orders (Ephemeroptera, Plecoptera and Trichoptera) (SREPT), where SREPT $=23$ indicates no toxic effects and SREPT $<23$ denotes toxic effects. Toxicity values $\left(F_{\text {TOX }}\right)$ obtained by WHAM- $F_{\text {TOX }}$ were calculated from monthly data. Values are expressed as mean and standard deviation $( \pm S D)$.

\begin{tabular}{lcccccc}
\hline Sites & SR $_{(\mathrm{EPT})}$ & Total $\_F_{\text {TOX }}$ & $F_{\text {TOX-Zn }}$ & $F_{\text {TOX- Pb }}$ & $F_{\text {TOX-H }}$ & $F_{\text {TOX-Al }}$ \\
\hline H15 & 10 & 4.0 & $1.7( \pm 0.7)$ & $0.2( \pm 0.1)$ & $1.4( \pm 0.4)$ & $0.4( \pm 0.5)$ \\
H14 & 13 & 3.6 & $1.6( \pm 0.5)$ & $0.1( \pm 0.0)$ & $1.2( \pm 0.3)$ & $0.3( \pm 0.5)$ \\
H13 & 9 & 4.1 & $0.0( \pm 0.1)$ & $0.0( \pm 0.0)$ & $2.6( \pm 0.3)$ & $1.4( \pm 0.3)$ \\
H12 & 15 & 3.3 & $2.3( \pm 0.9)$ & $0.2( \pm 0.1)$ & $1.0( \pm 0.3)$ & $0.2( \pm 0.5)$ \\
H11 & 20 & 2.8 & $0.1( \pm 0.3)$ & $0.0( \pm 0.0)$ & $1.8( \pm 0.6)$ & $0.3( \pm 0.2)$ \\
H10 & 19 & 2.8 & $0.7( \pm 0.3)$ & $0.1( \pm 0.0)$ & $1.2( \pm 0.4)$ & $0.1( \pm 0.1)$ \\
H9 & 18 & 3.0 & $0.1( \pm 0.1)$ & $0.0( \pm 0.0)$ & $2.0( \pm 0.7)$ & $0.4( \pm 0.2)$ \\
H8 & 23 & 1.7 & $0.5( \pm 0.2)$ & $0.0( \pm 0.0)$ & $0.9( \pm 0.3)$ & $0.1( \pm 0.1)$ \\
H7 & 18 & 3.0 & $2.0( \pm 0.3)$ & $0.0( \pm 0.0)$ & $1.0( \pm 0.2)$ & $0.0( \pm 0.1)$ \\
H6 & 20 & 2.7 & $0.8( \pm 0.2)$ & $0.0( \pm 0.0)$ & $1.2( \pm 0.3)$ & $0.2( \pm 0.3)$ \\
H5 & 23 & 2.3 & $0.9( \pm 0.2)$ & $0.1( \pm 0.1)$ & $1.1( \pm 0.2)$ & $0.1( \pm 0.2)$ \\
H4 & 8 & 4.2 & $0.0( \pm 0.0)$ & $0.0( \pm 0.0)$ & $3.3( \pm 0.4)$ & $0.9( \pm 0.3)$ \\
H3 & 23 & 1.2 & $0.1( \pm 0.0)$ & $0.0( \pm 0.0)$ & $1.0( \pm 0.3)$ & $0.0( \pm 0.1)$ \\
H2 & 22 & 2.4 & $0.6( \pm 0.2)$ & $0.0( \pm 0.0)$ & $1.3( \pm 0.4)$ & $0.2( \pm 0.3)$ \\
H1P & 23 & 1.9 & $0.1( \pm 0.0)$ & $0.0( \pm 0.0)$ & $1.5( \pm 0.6)$ & $0.2( \pm 0.1)$ \\
H1 & 23 & 1.5 & $0.3( \pm 0.0)$ & $0.0( \pm 0.1)$ & $0.8( \pm 0.2)$ & $0.0( \pm 0.1)$ \\
\hline
\end{tabular}

103

104 Contributions of metal toxic effects $\left(F_{\text {Tox }}\right)$ at different $\mathrm{pH}$ conditions were predicted by WHAM-

$105 F_{\text {TOX }}$ (Figure 7). Figure fa demonstrates the effects of heavy metals at spoil runoff or adit sites.

Higher toxicity (>2.3) is related to acidic waters $(\mathrm{H} 4$ and $\mathrm{H} 13)$, while adits or water draining through spoil sites are rich in $\mathrm{Zn}$ and $\mathrm{Pb}(\mathrm{H} 15, \mathrm{H} 14, \mathrm{H} 12, \mathrm{H} 7)$. Fig $7 \mathrm{~b}$ highlights the lack of metal contribution of metals at the lower $\mathrm{pH}$ sites $(\mathrm{pH}<5)$ due low metal-humic binding as a result of enhanced competition for binding sites from the elevated $\mathrm{H}$ and $\mathrm{Al}$ concentrations (and possible lower metal too). 

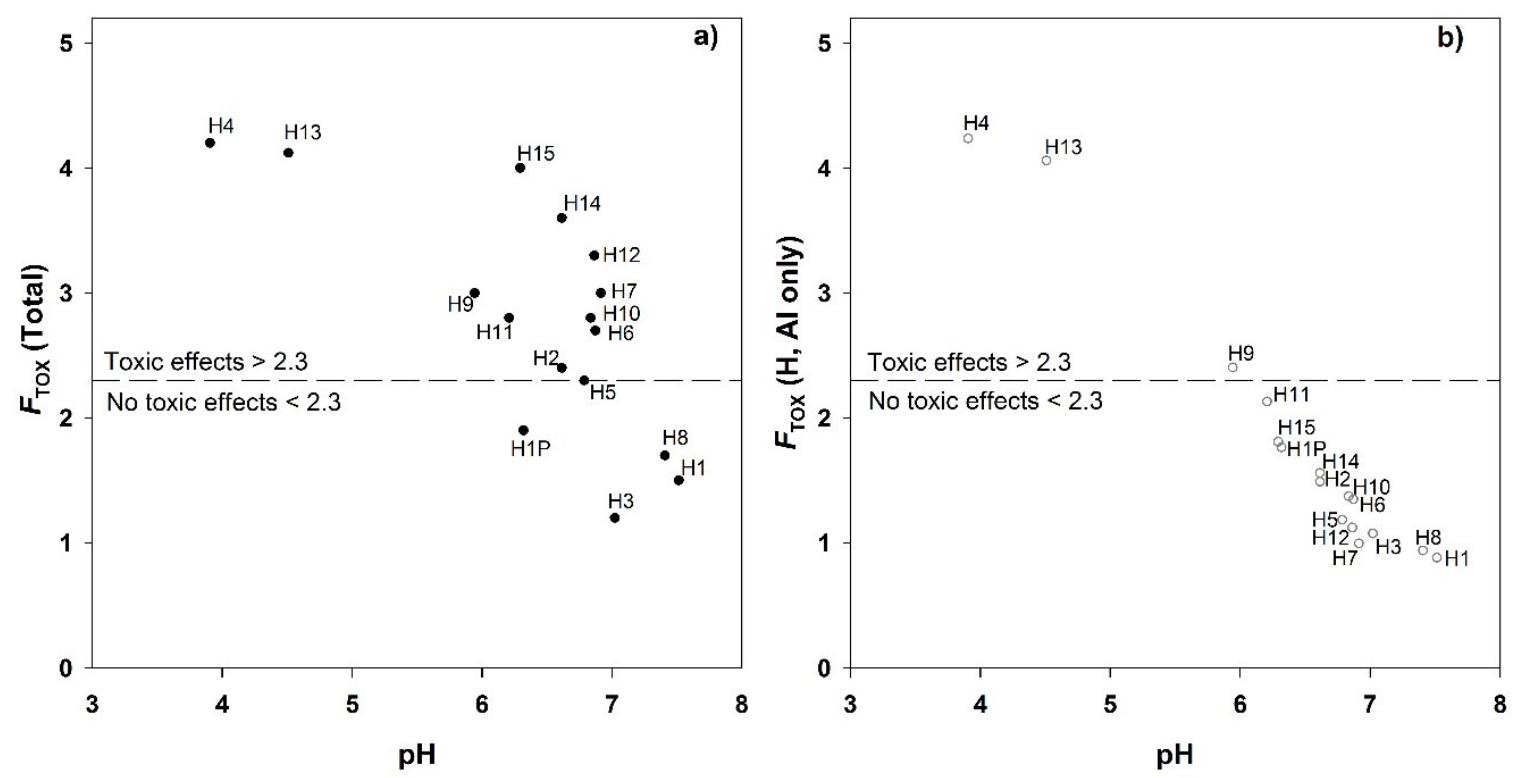

115

116

117

118

119

120

121

122

123

124

125

126

127

128

129

130

131

132

133

134

135

Figure 7. Variations of toxicity function $\left(F_{\text {TOX }}\right)$ with $\mathrm{pH}$. Panel a shows total $F_{\text {TOX }}$, which includes the effect of metals derived from mine-affected areas and acid contribution from peat soils. Panel $b$ shows the contribution of only $\mathrm{H}$ and $\mathrm{Al}$ to $F_{\text {TOX. }}$. The horizontal dashed line represents the $F_{\text {TOX }}$ threshold (2.3), above which toxic effect are predicted to occur. The upper limit of the plot represents the upper threshold (5.2).

\subsection{Evaluation of metal assessment tools}

EQS-H, EQS-B and WHAM- $F_{\text {TOX }}$ were compared to evaluate their relative assessment of potential impact with respect to metal toxicity in aquatic ecosystems (Table 2). Multiple sites are necessary as WFD applies to lower order streams than previous legislation, meaning all perennial tributaries may be important from a compliance viewpoint. Each of these sites represents a length of stream therefore an ecosystem. Ephemeral tributaries are assessed as they can represent high input sites into other streams, although these sites may not be significant as aquatic ecosystems as they are more likely to be dry during the productive summer months. From the comparison, EQS-H are more conservative than EQS-B. EQS-H showed wider ranges of exceedance for $\mathrm{Zn}(0.2$ to 254 -fold $)$ and for $\mathrm{Pb}$ (0.02 to 40 -fold), while compared to EQS-B for $\mathrm{Zn}(0.8$ to 209 -fold $)$ and $\mathrm{Pb}$ (0.02 to 17 -fold). For both tools, the highest Zn failures occurred in reservoir $(\mathrm{H} 15)$, ephemeral tributary $(\mathrm{H} 12)$ and perennial tributaries ( $\mathrm{H} 14$ and $\mathrm{H} 7)$. For $\mathrm{Pb}$, the same sites, except $\mathrm{H} 7$ showed significant failures, in addition, using EQS-H an ephemeral tributary $(\mathrm{H} 13)$ showed exceedance, likewise the perennial tributary 
(H5) applying the EQS-B approach. For the Pb bioavailability tools (FST and SSD), results

137 showed that the FST approach with fewer chemistry inputs is more conservative than SSD.

138 By using FST, values ranged from 0.1 to 35 -fold, while SSD presented ranges from 0.1 to $17-$

139 fold. Calculations from WHAM- $F_{\text {TOx }}$ showed that at twelve sites the water chemistry may

140 reduce the maximum species diversity of macroinvertebrates by between 3 and $65 \%$. All

141 ephemeral tributaries $(\mathrm{H} 12, \mathrm{H} 13$, and $\mathrm{H} 4)$ together with a perennial tributary $(\mathrm{H} 14)$ and

142 reservoir $(\mathrm{H} 15)$ showed the largest predicted reductions in species richness of $34 \%$ to $65 \%$.

\section{$143 \quad$ 3.7. In situ macroinvertebrate survey}

144 A total of twenty four macroinvertebrate families were identified across all of the sites. The

145 BMWP scores based on the presence and absence of macroinvertebrates families indicated

146 a moderately impacted water quality (BMWP > 50) for sites $\mathrm{H} 14, \mathrm{H} 10, \mathrm{H} 9, \mathrm{H} 6, \mathrm{H} 5, \mathrm{H} 3, \mathrm{H} 2$,

$147 \mathrm{H} 1 \mathrm{P}$ and $\mathrm{H} 1$ representing mainly main channel sites Lower scores (BMWP $<25)$ in sites 148 representing source waters and tributaries $(\mathrm{H} 15, \mathrm{H} 13, \mathrm{H} 12, \mathrm{H} 11, \mathrm{H} 8, \mathrm{H} 7$ and $\mathrm{H} 4)$ indicated 149 pollution deriving poor water quality (Figure S1), while ASTP scores $(<2)$ showed sites H13 150 and $\mathrm{H} 12$ as the most polluted (Figure \$2), although ephemeral tributaries may expected to 151 have reduced or poor biological diversity due to periodic dry periods, particularly in the summer 152 months.

153 Four macroinvertebrate orders were predominant in the catchment (Figure S3). Based on numbers of total individuals counted, the order Diptera showed $40 \%$ represented by the families Psychodidae and Simuliidae (Figure S4), followed by the order Ephemeroptera (mayfly) with $18 \%$ where Baetidae was the most prevalent (Figure S5), Trichoptera (caddisfly)

157 presented $28 \%$ with Hydropsychidae as the dominant family (Figure S6), and the order 158 Plecoptera (stonefly) with 11\% represented by the family Perlodidae (Figure S7).

\section{Discussion}

160 For aquatic environments, metal assessment has evolved as bioavailability is increasingly 161 considered a critical measure for improving water quality, e.g. under the EU Water Framework 
Directive. A preliminary water quality assessment was carried out where dissolved concentrations of $\mathrm{Zn}$ and $\mathrm{Pb}$ were assumed to be bioavailable depending on ranges of water hardness conditions, and exceedances were calculated from previous-established EQS-H. Concentrations of $\mathrm{Zn}$ and $\mathrm{Pb}$ exceeded the limits by 175-fold and 40-fold respectively, however, little consideration is given to their bioavailable forms. Merrington (2016) has indicated that hardness limits have been derived from ecotoxicological tests mainly from crustaceans and fish, where water chemical parameters do not necessarily reflect field conditions. Thus, the use of hardness-based standards may be overly conservative as they might under-represent other important taxa. In addition, they fail to consider chemical speciation in distinguishing sites with potential environmental risk associated with metals.

In complex environments such as freshwaters, understanding of the underlying conditions controlling the dynamics and speciation of metals is critical for assessing and managing the risk they pose to aquatic life (Han et al., 2013). This study evaluated the utility of DGT for yielding both time averaged and dynamic $\mathrm{Zn}$ and $\mathrm{Pb}$ concentrations (potentially a proxy for organism availability) (Diviš et al., 2007; Degryse et al., 2009; Amato et al., 2014; Søndergaard et al., 2011; 2014; Omanović et al., 2015). By comparing, DGT measurements ( $\left.C_{\mathrm{DGT}}\right)$ with direct water measurements (M-measured), results indicated that $C_{\mathrm{DGT}}$ concentrations were generally lower than the directly measured values. For $\mathrm{Zn}-C_{\mathrm{DGT}}$ and $\mathrm{Zn}$-measured a strong linear correlation $\left(R^{2}=0.75\right)$ was present suggesting the presence of $Z n$ mainly as free ions and readily labile complexes, a slope of 0.47 revealed that DGT measurements at higher concentrations failed to reflect dissolved measured concentrations. The better agreement presented at lower concentrations might be caused by the kinetic rate of $\mathrm{Zn}$ forms, which will determine its accumulation into the Chelex-resin layer (Warnken et al., 2007). Free $\mathrm{Zn}^{2+}$ seems to be rapidly absorbed by the Chelex-resin layer, while the supply of labile complexed forms will depended on their degree of lability (Puy et al., 2012). Zhang and Davison (2015) indicated that fully labile complexes might not be completely dissociated within the diffusion layer, thus their uptake in the Chelex-resin could be reduced or not occur. Correlation between 
$\mathrm{Pb}-C_{\mathrm{DGT}}$ and $\mathrm{Pb}$-measured was moderate $\left(\mathrm{R}^{2}=0.59\right)$, with a slope of 0.07 indicating poor

190 agreement between the data, attributable to the presence of less labile $\mathrm{Pb}$ forms (e.g. $\mathrm{Pb}$ -

191 FeOx, $\mathrm{Pb}-\mathrm{DOM})$ that need more time for diffusion or presence of bigger particles that could 192 be excluded from DGT membranes (Han et al., 2013). Considering correlations for both metals, $C_{\mathrm{DGT}}$ measurements can be affected by the amount of total metal dissolved concentrations present as free ions and their complexation with inorganic or forganic substances (Zhang and Davison, 2015). Furthermore, long deployments (> 15 days) might expose DGTs to biological factors like biofouling, and flow fluctuations that might decrease the stirring rates, reducing DGT's performance (Davison and Zhang, 1994: Webband Keough, 2002; Turner et al., 2014).

Metal speciation and bioavailability are controlled by a range of different factors such as $\mathrm{pH}$, ionic strength, DOC, hardness, $\mathrm{pH}$ and inorganic or organic colloids. Given these factors, the quantity of metal available for organism uptake is not reflected by the total dissolved concentration (Hart, 1981; Luoma, 2008). This study correlated M-C $C_{D G T}$ measurements with inorganic metal complexes predicted from dissolved measured concentrations under the absence and presence of active inorganic colloids (e.g. FeOx and AIOx) as they can compete for $\mathrm{Zn}$ and $\mathrm{Pb}$ binding with DOM. If active oxide colloids are excluded from the modelling, $\mathrm{Zn}$ is predicted to be largely present as inorganic (e.g. $\mathrm{Zn}^{2+}, \mathrm{Zn}(\mathrm{OH})^{+}$, etc.) rather than organic complexes, and highest predicted inorganic concentration was at site $\mathrm{H} 12\left(5.8 \times 10^{-5} \mathrm{~mol} / \mathrm{l}\right)$.

208 Conversely Pb had a greater affinity for organic binding, with highest organic concentration at $209 \mathrm{H} 15\left(10^{-6} \mathrm{~mol} / \mathrm{l}\right)$ (Figure 5). Both metals showed good linear correlations between inorganic 210 complexes and $C_{\mathrm{DGT}}$ for $\mathrm{Zn}\left(\mathrm{R}^{2}=0.81\right)$, and $\mathrm{Pb}\left(\mathrm{R}^{2}=0.54\right)$, reflecting a modest improvement

211 in the correlation of $\mathrm{Zn}-C_{\mathrm{DG}}$ with predicted $\mathrm{Zn}$ inorganic complexes than previous correlation

212 between $\mathrm{Zn}-\mathrm{C}_{\mathrm{DG}}$ with $\mathrm{Zn}$-measured, which can be attributable to the fact that dissolved $\mathrm{Zn}$ is present primarily as inorganic and free ions, reflecting the absence or low level of Zn-organic 214 complexes in the correlation analysis. The agreement observed for $\mathrm{Zn}$ confirms that the total 215 dissolved $\mathrm{Zn}$ (mainly inorganic) is approximately equivalent to the dynamic $\mathrm{Zn}-C_{\mathrm{DG}}$ (except at 
high $\mathrm{Zn}$ loading, as previously discussed). For $\mathrm{Pb}$, there is a discrepancy between $\mathrm{Pb}-\mathrm{C}_{\mathrm{DG}}$

217 and dissolved $\mathrm{Pb}$, likely due to larger fractions in other less labile phases (Pb-organic 218 complexes) (Warnken et al., 2008; Han et al., 2013). Outcomes from modelling conditions 219 where oxide precipitates are surface reactive showed similar behaviours for $\mathrm{Zn}\left(R^{2}=0.81\right)$ and $\mathrm{Pb}\left(\mathrm{R}^{2}=0.51\right)$ to those obtained in the absence of surface activity. The lack of improved agreement to the $\mathrm{Pb}$-inorganic in presence of oxides with the $\mathrm{Pb}-\mathrm{C}_{\mathrm{DGT}}$ (dynamic) concentration implies that the model may be under-predicting the binding to these forms. Results from DGT measurements provided useful information about metal dynamics and speciation which is valuable for understanding metal uptake mechanisms. Metal bioavailability studies from Bradac et al. (2009); Yin et al. (2014); (Balistrieri et al., 2012) suggest DGTs as useful tool for understanding the accumulation of metals in freshwater ecosystems (e.g. algae, snails and fish). However, results from this study indicated that DGT is not a suitable substitute for direct water measurements due to complex uptake kinetics of different forms and at higher metal concentrations. These limitations make DGT a potentially useful bioavailability assessment tool, but further work is needed to compare DG measurements in the field with actual in situ organism metal burdens. Zhang and Davison (2015) have indicated that given the complexity of biological system and chemistry of environmental media, the ability of DGT to mimic metal uptake and predict bioavailability is variable. Further research based on the comparison of field data and laboratory experiments under controlled temperature, deployment time and flow rates are suggested for evaluating the applicability of DGTs regarding metal bioavailability in freshwaters. Evidence of marked diurnal ranges as well as flow-dependent variations in metal concentrations reported by Jones et al. (2015), also suggests that DGT measurements should be complemented by frequent measurements of metal concentrations (e.g. with auto samplers) to identify the actual variation experienced by DGTs.

Outcomes from EQS-H, EQS-B and $W H A M-F_{\text {TOx }}$ provided different levels of prediction regarding metal bioavailability and toxicity. In comparing EQS-H and EQS-B, the simpler approach $(E Q S-H)$ is more conservative than the standard that considered more water 
chemistry parameters and metal-organism interactions (EQS-B) (Merrington, 2016). However,

244 by contrasting EQS-B and WHAM-FTOX, results suggest that the latter approach is the least 245 conservative of the three approaches. This was clearly identified in sites which exceeded 246 EQS-B like H7 (Zn: 209-fold and Pb: 2-fold) and H5 (Zn: 44-fold and Pb: 9-fold), but with $F_{\text {Tox- }}$ 247 SR showing $100 \%$ for predicted species richness for both sites. WHAM- $F_{\text {TOx }}$ also revealed 248 that major toxic effects can occur at circumneutral $\mathrm{pH}$ mostly due to $\mathrm{Zn}$ and $\mathrm{Pb}$. Moreover, a 249 limited biological survey agreed with this chemical assessment. The most impoverished sites 250 presented low predicted macroinvertebrate richness ( $S R_{E P T} \leq 34 \%$ ) correlating with high concentrations of metals $(\mathrm{H} 12, \mathrm{H} 13$ and $\mathrm{H} 14)$ or low-pH values $(\mathrm{H} 4)(\mathrm{Table} 2)$ - Overall, the orders Diptera and Trichoptera were dominant (40\% and $28 \%$ with Chironomidae and Hydropsychidae as the more abundant families. Responses of macroinvertebrates and diatoms to different metal levels in Hebden Beck have been previously evaluated by the Environment Agency (2014). The ecological assessment revealed a relationship between increasing $\mathrm{Zn}$ concentrations and reduced biodiversity. Likewise invertebrate data showed that responses of species diversity and composition could be related to the influence of complex interactions between metals and acid scenarios. In early and current assessment, the family Baetidae (O: Ephemeroptera) was dominant, possibly due to its tolerance to different levels of pollution. A study by Mebane et al. (2015), indicated that the species most sensitive to pollution are the last to re-colonise after recovery from Cu contamination. In our study less sensitive families (Perlodidae, Nemouridae, Baetidae) are widespread throughout the catchment. More sensitive families like Glossomidae, Ephemerellidae and Heptageniidae are mainly confined to main channel sites $(\mathrm{H} 2, \mathrm{H} 6, \mathrm{H} 10)$, although Heptageniidae was also present in a metal impacted site $\mathrm{H} 14$ (predicted species richness of $55 \%$ of the theoretical maximum), another metal sensitive family, Psychodidae was present in less metal impacted sites, such as $\mathrm{H} 1 \mathrm{P}$, showing a predicted species richness of $100 \%$. These results are consistent with the $F_{\text {TOX }}$ species predictions, however, current interpretations are generalised as we only identified macroinvertebrates to family level, and species sensitivity is complex,

270 where differences in pollution tolerance occur within different taxa (Clements et al., 2013). 
271 From a regulatory perspective, bioavailability based standards (EQS-B) offer a more 272 ecologically-based approach to address water quality failures than traditional hardness 273 corrections (EQS-H) (Peters et al., 2016), due to their parameterisation with organism toxicity 274 data or field species observations. In this study, both standards facilitated the screening of 275 sites with potential metal risk, however, EQS-B identified sites where dissolved metal concentrations and speciation mechanisms $\left(\mathrm{M}-C_{\mathrm{DGT}}\right)$ were related. Although, bioavailabilitybased models have been developed on field data and applied in the establishment of water 278 quality standards for metals, their applicability for routine regulatory purposes need to be tested, especially for sites where physicochemical conditions (e.g.pH, hardness, DOC) are near or outside of the boundaries of the model (Rüdel et al., 2015, WFD-UKTAG, 2009a). In this study, some sites presented $\mathrm{pH}$ and Ca values below Zn-BLM limits, thus default limits of this tool $(\mathrm{pH}=6$ and $\mathrm{Ca}=3 \mathrm{mg} / \mathrm{l})$ were used in $\mathrm{Zn}$ assessment, consequently the use of complementary models like WHAM and WHAMFTox can offer more complete toxicity predictions under original physico-chemical conditions. Because $\mathrm{WHAMF}_{\text {TOx }}$ considers protons within its formulation, it can be applied to any combination of water chemistry and metal mixtures. Bioavailability based EQS were implemented for England and Wales in 2014 (DEFRA, 2014). For a practical implementation of these tools a compliance scheme was suggested by the UK TechnicalAdvisory Group, which includes: i) comparison between metal concentrations with EQS-H, ii) application of BLM tools (e.g. Zn-BLM, Pb-BLM) to predict sitespecific bioavailability (EQS-B), and iii) local refinement by using models that require larger number of input parameters (e.g. full M-BLM or WHAMFTox) (Bio-met, 2015; WFD-UKTAG, 2009 b) Further research is desirable, especially in the generation of toxicity data to improve the sighificance of toxicity coefficients (e.g. $\left.\alpha_{\mathrm{Pb}}\right)$. Nevertheless, the combination of EQS-B and WHAM- $F_{\text {TOx }}$ could provide an improved rational assessment which is essential for the purposes of considering remediation activities. Vulnerable sites can be prioritised under a holistic scenario (water chemistry, metal concentrations and interactions between metal and organism) where remedial actions can be focused on reducing metal bioavailability for the purpose of improving ecological endpoints. 
This study has evaluated different methods for the assessment of the chemical and ecological

300 status of Hebden catchment regarding metal pollution. The first method (EQS-H) was a simple and well-established technique, which provided a very conservative regulatory limit that may be overprotective as seen when calculations are performed with tools designed specifically to account for speciation and organisms interactions. The second (EQS-B) and third (WHAM$F_{\text {TOx }}$ method based on more rigorous bioavailability tools (e.g. Zn-BLM and Pb-SSD), provided less conservative limits but supported by the normalisation of the ecotoxicity data to the site specific water chemistry. Through the evaluation of these approaches a better understanding of metal speciation and dynamics was possible, supporting the prediction of toxic effects from metal mixtures and the identification of sites with potential biological risks. Furthermore, the biological survey provided a context for relating the response of aquatic organisms to river water chemistry and pollutants, which are useful for future ecological 311 assessments.

\section{Conclusions}

313 The use of bioavailability-based standards is needed to fully assess the impacts of metal pollution and implement regulatory actions for delivering good ecological status.

315 - In carboniferous catchments, metal toxic effects occur at circumneutral pH. Zn is mainly

316 present as free ions and readily labile complexes while $\mathrm{Pb}$ is present as less labile forms 317 (e.g. organic complexes and colloids).

318 - Metal assessment through the EQS-H approach is more conservative than EQS-B and 319 WHAM-F $F_{\text {TOX }}$. The incorporation of bioavailability will better address some of the processes 320 that control toxic metals effects. In addition, catchment management will be improved as 321 the bioavailability approach will aid in the identification of key reaches where remediation may be required.

- Metal concentrations estimated from DGT provided useful information for the assessment of $\mathrm{Zn}$ and $\mathrm{Pb}$ speciation and for understanding metal uptake mechanisms. However, results 
suggest that further research is required for evaluating the applicability of this tool in the assessment of metal bioavailability under field conditions.

327

328

329

330

331

332

333

334

335

336

337

338

339

340

341

342

343

344

345

346

347

348

349

350

351

352

353

354

355

356

357

358

\section{Acknowledgments}

This research was funded by the National Secretariat for Higher Education, Sciences, Technology and Innovation of Ecuador (SENESCYT in Spanish) through a PhD scholarship granted to M. Valencia-Avellan in June 2013 (Grant No. 82-ARG5-2013). We thank Dr Vicky Hirst for her expertise in the performance of the biological survey and the Environment Agency for sharing scientific reports and supporting this research. We also thank the anonymous reviewers for their helpful comments.

\section{References}

Amato, E.D., Simpson, S.L., Jarolimek, C.V. and Jolley, DF (2014) Diffusive Gradients in Thin Films Technique Provide Robust Prediction of Metal Bioavailability and Toxicity in Estuarine Sediments. Environmental Science \& Technology 48(8), 4485-4494.

Armitage, P.D., Moss, D., Wright, J.F. and Furse, M.T. (1983) The performance of a new biological water quality score system based on macroinvertebrates over a wide range of unpolluted running-water sites. Water-Research-17(3), 333-347.

Balistrieri, L.S. and Blank, R.G. (2008) Dissolved and labile concentrations of $\mathrm{Cd}, \mathrm{Cu}, \mathrm{Pb}$, and $\mathrm{Zn}$ in the South Fork Coeur didene River, Idaho: Comparisons among chemical equilibrium models and implications for biotic ligand models. Applied Geochemistry 23(12), 3355-3371.

Balistrieri, L.S. and Mebane, C.A. (2014) Predicting the toxicity of metal mixtures. Science of the Total Environment 466-467, 788-799.

Balistrieri, L.S.,Nimick, D.A. and Mebane, C.A. (2012) Assessing time-integrated dissolved concentrations and predicting toxicity of metals during diel cycling in streams. Science of the Total Environment 425, 155-168.

Beane, S.J., Comber, S.D.W., Rieuwerts, J. and Long, P. (2016) Abandoned metal mines and their impact on receiving waters: A case study from Southwest England. Chemosphere 153, 294-306.

Benedetti, M.F., Milne, C.J., Kinniburgh, D.G., Van Riemsdijk, W.H. and Koopal, L.K. (1995) Metal Ion Binding to Humic Substances: Application of the Non-Ideal Competitive Adsorption Model. Environmental Science \& Technology 29(2), 446-457.

Bio-met. (2015) Technical guidance to implement bioavailability-based environmental quality standards for metals. [Online]. Available from: http://bio-met.net/wpcontent/uploads/2016/10/FINAL-TECHNICAL-GUIDANCE-TO-IMPLEMENT-

BIOAVAILABILITYApril-2015.pdf, [Accessed 5 March 2016]. 
Bradac, P., Navarro, E., Odzak, N., Behra, R. and Sigg, L. (2009) Kinetics of cadmium accumulation in periphyton under freshwater conditions. Environmental Toxicology and Chemistry 28(10), 2108-2116.

Buffle, J.a.H., G. (2000) In situ Monitoring of Aquatic Systems. IUPAC Series in Analytical and Physical Chemistry of Environmental Systems, Wiley, Chichester.

Campbell, P.G.C. (1995) Metal Speciation and Bioavailability in Aquatic Systems. Tessier,

Cheng, T., Schamphelaere, K.D., Lofts, S., Janssen, C. and Allen, H.E. (2005) Measurement and computation of zinc binding to natural dissolved organic matter in European surface waters. Analytica Chimica Acta 542(2), 230-239.

Clements, W.H., Cadmus, P. and Brinkman, S.F. (2013) Responses of Aquatic Insects to Cu and $\mathrm{Zn}$ in Stream Microcosms: Understanding Differences Between Single Species,Tests and Field Responses. Environmental Science \& Technology 47(13), 7506-7513

372 Davison, W. and Zhang, H. (1994) In situspeciation measurements of trace components in natural waters using thin-film gels. Nature 367(6463), 546-548

De Schamphelaere, K.A.C. and Janssen, C.R. (2002) A Biotic Ligand Model Predicting Acute Copper Toxicity for Daphnia magna: The Effects of Calcium, Magnesium, Sodium, Potassium, and $\mathrm{pH}$. Environmental Science \& Technology 36(1), 48-54.

de Vries, W., Lofts, S., Tipping, E., Meili, M., Groenenberg, J.E. and Schütze, G. (2007) Reviews of Environmental Contamination and Toxicology, pp. 47-89, Springer New York, New York, NY.

DEFRA. (2014) Water Framework Directive implementation in England and Wales: new and updated standards to protect the water environment. Department for Environment, Food \& $\begin{array}{llll}\text { Rural Affairs. Available } & \text { Anline]. }\end{array}$ http://www.gov.uk/government/up/oads/system/uploads/attachment_data/file/307788/riverbasin-planning-standards.pdf, [Accessed 10 April 2016].

Degryse, F., Smolders, E., Zhang, H. and Davison, W. (2009) Predicting availability of mineral elements to plants with the DGT technique: a review of experimental data and interpretation by modelling. Environmental Chemistry 6(3), 198-218.

DGT Research. (2015) DGT Research: For measurements in water, soils and sediments. [Online] Available from: http://www.dgtresearch.com/, [Accessed 1 November 2015].

Divišs. P., Dočekalová, H., Brulík, L., Pavliš, M. and Hekera, P. (2007) Use of the diffusive gradients in thin films technique to evaluate (bio) available trace metal concentrations in river water. Analytical and bioanalytical chemistry 387(6), 2239-2244.

395 Environment Agency (2014) Ecological sampling to assess the impacts of metal pollution

Dzombak, D.A. and Morel, F.M. (1990) Surface complexation modeling: hydrous ferric oxide, John Wiley \& Sons.

397 Environment Agency. (2011) Chemical Standards Data Base. [Online]. Available from: 398 http://evidence.environment-agency.gov.uk/ChemicalStandards/Home.aspx, [Accessed 30 399 March 2016]. 
400 Environment Agency. (2008a) Abandoned mines and the water environment. Science project

402 http://www.gov.uk/government/uploads/system/uploads/attachment_data/file/291482/LIT_88

403 79_df7d5c.pdf, [Accessed 20 March, 2017].

404 Environment Agency. (2008b) Environmental Quality Standards for trace metals in the aquatic 405 environment. Science Report SC030194/SR. [Online]. Available from: 406 http://nora.nerc.ac.uk/3209/1/SCHO0408BNXX-e-e.pdf, [Accessed 25 March 2016].

407 EU-STAR project. (2004) UK Invertebrate sampling and analysis procedure. [Online]. 408 Available from: http://www.eu-star.at/pdf/RivpacsMacroinvertebrateSamplingProtocol.pdf, 409 [Accessed 15 April 2016].

410 European Commission (2000) Water Framework Directive 2000/60/EC. Official Journal L 827 , 411 22/12/2000 P. 0001 - 0073.

412 Hall, J.R., Ashmore, M., Fawehinmi, J., Jordan, C., Lofts, S., Shotbolt, Spurgeon, D.J., 413 Svendsen, C. and Tipping, E. (2006) Developing a critical load approach for national risk 414 assessments of atmospheric metal deposition. Environmental Toxicology and Chemistry 415 25(3), 883-890.

416 Hamilton-Taylor, J., Ahmed, I.A.M., Davison, W. and Zhang, H. (2011) How well can we 417 predict and measure metal speciation in freshwaters? Environmental Chemistry 8(5), 461418465

419 Han, S., Naito, W., Hanai, Y. and Masunaga, S. (2013) Evaluation of trace metals

bioavailability in Japanese river waters using DGT and chemical equilibrium model. Water Research 47(14), 4880-4892.

422 Harmsen, J. and Naidu, R. (2013) Bioavailabjlity as a tool in site management. Journal of

424 Hart, B.T. (1981) Trace metal complexing capacity of natural waters: a review. Environmental

He, E. and Van Gestel, C.A.M. (2015) Delineating the dynamic uptake and toxicity of Ni and Co mixtures in Enchytraeus crypticus using a WHAM-FTOX approach. Chemosphere 139,

$428 \quad 216-222$.

429 International Lead Association. (2017) Lead Chronic Biotic Ligand Model Tool. [Online]. 430 Available from http://www.ila-lead.org/responsibility/lead-blm-tool, [Accessed 2 July 2016].

431 Jarvis, A.P and Younger, P.L. (2000) Broadening the scope of mine water environmental 96.

434 Jones, A., Rogerson, M., Greenway, G. and Mayes, W.M. (2015) Zinc Uptake from 435 Circumneutral Mine Drainage in Freshwater Biofilms: New Insights from In Vitro Experiments. 436 Mine Water and the Environment 34(3), 295-307.

437 Jones, A., Rogerson, M., Greenway, G., Potter, H.A.B. and Mayes, W.M. (2013) Mine water 438 geochemistry and metal flux in a major historic Pb-Zn-F orefield, the Yorkshire Pennines, UK. 
Kalis, E.J.J., Weng, Dousma, F., Temminghoff, E.J.M. and Van Riemsdijk, W.H. (2006) Measuring Free Metal Ion Concentrations in Situ in Natural Waters Using the Donnan Membrane Technique. Environmental Science \& Technology 40(3), 955-961.

443 Lock, K., Van Eeckhout, H., De Schamphelaere, K.A.C., Criel, P. and Janssen, C.R. (2007) Development of a biotic ligand model (BLM) predicting nickel toxicity to barley (Hordeum vulgare). Chemosphere 66(7), 1346-1352.

Lofts, S. (2012) User's guide to WHAM7. NERC Centre for Ecology and Hydrology , Lancaster, UK.

Lofts, S. and Tipping, E. (2011) Assessing WHAM/Model VII against field measurements of free metal ion concentrations: model performance and the role of uncertainty in parameters and inputs. Environmental Chemistry 8(5), 501-516.

Luoma, S., Rainbow, P. (2008) Metal contamination in Aquatic Environments Science and Lateral Management, Cambridge University Press, New York, United States.

Mayes, W.M., Johnston, D., Potter, H.A.B. and Jarvis, A.P. (2009) A national strategy for identification, prioritisation and management of pollution from abandoned hon-coal mine sites in England and Wales. I.: Methodology development and initial results. Science of the Total Environment 407(21), 5435-5447.

Mebane, C.A., Eakins, R.J., Fraser, B.G. and Adams, W.J.(2015) Recovery of a miningdamaged stream ecosystem. Elementa 3.

Merrington, G. (2016) Accounting for metal bioavailability in assessing water quality: A step change? Environ Toxicol Chem v. 35(no 2), pp. 257- 265.

Merrington, G. and Peters, A. (2013) Development and use of the zinc bioavailability tool (draft). United Kingdom Technical Advisory Group (WFD-UKTAG). Report:SC080021/1g_a. [Online]. Available from: http://www.wfduk.org/resources/category/environmental-standardmethods-203, [Accessed 15July 2016].

Namieśnik, J. and Rabajczyk, A. (2010) The speciation and physico-chemical forms of metals in surface waters and sediments. Chemical Speciation \& Bioavailability 22(1), 1-24.

Niyogi, S. and Wood, C.M. (2004) Biotic Ligand Model, a Flexible Tool for Developing SiteSpecific Water Quality Guidelines for Metals. Environmental Science \& Technology 38(23), 6177-6192.

Omanović, D., Pižeta, I., Vukosav, P., Kovács, E., Frančišković-Bilinski, S. and Tamás, J. (2015) Assessing element distribution and speciation in a stream at abandoned $\mathrm{Pb}-\mathrm{Zn}$ mining site by combining classical, in-situ DGT and modelling approaches. Science of the Total Environment 511, 423-434.

Paquin, P.R., Gorsuch, J.W., Apte, S., Batley, G.E., Bowles, K.C., Campbell, P.G.C., Delos, C.G., Di Toro, D.M., Dwyer, R.L., Galvez, F., Gensemer, R.W., Goss, G.G., Hogstrand, C., Janssen, C.R., McGeer, J.C., Naddy, R.B., Playle, R.C., Santore, R.C., Schneider, U., Stubblefield, W.A., Wood, C.M. and Wu, K.B. (2002) The biotic ligand model: a historical overview. Comparative Biochemistry and Physiology Part C: Toxicology \& Pharmacology 133(1-2), 3-35. 
environmental quality standard for nickel. Environmental Toxicology and Chemistry 35(10), 2397-2404.

484 Puy, J., Uribe, R., Mongin, S., Galceran, J., Cecília, J., Levy, J., Zhang, H. and Davison, W. (2012) Lability Criteria in Diffusive Gradients in Thin Films. The Journal of Physical Chemistry A 116(25), 6564-6573.

487 Qiu, H., Vijver, M.G., He, E., Liu, Y., Wang, P., Xia, B., Smolders, E., Versieren, L. and 488 Peijnenburg, W.J.G.M. (2015) Incorporating bioavailability into toxicity assessment of Cu-Ni, $489 \mathrm{Cu}-\mathrm{Cd}$, and Ni-Cd mixtures with the extended biotic ligand model and the WHAM-F tox 490 approach. Environmental Science and Pollution Research 22(23), 19213-19223.

Rüdel, H., Díaz Muñiz, C., Garelick, H., Kandile, N.G., Miller, B.W., Pantoja Munoz, L., Peijnenburg, W.J.G.M., Purchase, D., Shevah, Y., van Sprang, P., Vijver, M. and Vink, J.P.M. (2015) Consideration of the bioavailability of metal/metalloid species in freshwaters: experiences regarding the implementation of biotic ligand model-basedrapproaches in risk assessment frameworks. Environmental Science and Pollution Research 22(10), 7405-7421.

Søndergaard, J., Asmund, G., Johansen, P. and Rigét, F. (2011) Long-term response of an arctic fiord system to lead-zinc mining and submarine disposal of mine waste (Maarmorilik, West Greenland). Marine Environmental Research 71(5), 331-341.

499

500

501

502

Søndergaard, J., Bach, L. and Gustavson, K. (2014) Measuring bioavailable metals using diffusive gradients in thin films (DGT) and transplanted seaweed (Fucus vesiculosus), blue mussels (Mytilus edulis) and sea snails (Littorina saxatilis) suspended from monitoring buoys near a former lead-zinc mine in West Greenland. Marine Pollution Bulletin 78(1-2), 102-109.

503

504

505

506

507

508

509

510

511

512

513

514

515

516

517

518

519

520

521

524

Steenbergen, N.T., laccino, F., de Winkel, M Reijnders, L. and Peijnenburg, W.J. (2005) Development of a biotic ligand model and a regression model predicting acute copper toxicity to the earthworm Aporrectodea catiginosa. Environmental Science \& Technology 39(15), 5694-5702.

Stockdale, A., Tipping, E., Lofts, \$., Fott, J., Garmo, Ø.A., Hruska, J., Keller, B., Löfgren, S., Maberly, S.C., Majer, V.Nierzwicki-Bauer, S.A., Persson, G., Schartau, A.-K., Thackeray, S.J., Valois, A., Vrba, Walseng, B. and Yan, N. (2014) Metal and proton toxicity to lake zooplankton: A chemical speciation based modelling approach. Environmental Pollution 186, 115-125.

Stockdale, A., Tipping, E., Lofts, S., Ormerod, S.J., Clements, W.H. and Blust, R. (2010) Toxicity of proton-metal mixtures in the field: Linking stream macroinvertebrate species diversity to chemical speciation and bioavailability. Aquatic Toxicology 100(1), 112-119.

Tipping, E. (2002) Cation binding by humic substances, Cambridge University Press, Cambridge.

Tipping, E. (2005) Modelling Al competition for heavy metal binding by dissolved organic matter in soil and surface waters of acid and neutral pH. Geoderma 127(3), 293-304.

Tipping, E. (1994) WHAMC-A chemical equilibrium model and computer code for waters, sediments, and soils incorporating a discrete site/electrostatic model of ion-binding by humic substances. Computers \& Geosciences 20(6), 973-1023.

Tipping, E., Jarvis, A.P., Kelly, M.G., Lofts, S., Merrix, F.L. and Ormerod, S.J. (2009) Ecological indicators for abandoned mines, Phase 1: Review of the literature. Environment Agency Report: SC030136/R49. [Online]. Available from: 
525 http://www.gov.uk/government/publications/ecological-indicators-for-abandoned-mines,

526 [Accessed 30 July 2016].

527 Tipping, E. and Lofts, S. (2013) Metal mixture toxicity to aquatic biota in laboratory 528 experiments: Application of the WHAM-FTOX model. Aquatic Toxicology 142-143, 114-122.

529 Tipping, E. and Lofts, S. (2015) Testing WHAM-FTOX with laboratory toxicity data for mixtures

530 of metals (Cu, Zn, Cd, Ag, Pb). Environmental Toxicology and Chemistry 34(4), 788-798.

531 Tipping, E., Lofts, S. and Sonke, J. (2011) Humic Ion-Binding Model VII: a revised 532 parameterisation of cation-binding by humic substances. Environmental Chemistry 8(3), 225533235.

534 Tipping, E., Rieuwerts, J., Pan, G., Ashmore, M.R., Lofts, S., Hill, M.T.R., Farago, M.E.and 535 Thornton, I. (2003) The solid-solution partitioning of heavy metals (Cu, Zn, Cd, Pb) in upland 536 soils of England and Wales. Environmental Pollution 125(2), 213-225.

537 Tipping, E., Vincent, C.D., Lawlor, A.J. and Lofts, S. (2008) Metal accumulation by stream 538 bryophytes, related to chemical speciation. Environmental Pollution 156(3), 936-943.

539 Turner, G.S., Mills, G.A., Bowes, M.J., Burnett, J.L., Amos, S. and Fones, G.R. (2014) 540 Evaluation of DGT as a long-term water quality monitoring tool in natural waters; uranium as 541 a case study. Environmental Science: Processes \& Impacts 16(3), 393-403.

542 Unsworth, E.R., Warnken, K.W., Zhang, H., Davison, W., Black, F., Buffle, J., Cao, J., Cleven, 543 R., Galceran, J., Gunkel, P., Kalis, E., Kistler, D. van Leeuwen, H.P., Martin, M., Noël, S., 544 Nur, Y., Odzak, N., Puy, J., van Riemsdijk, W Sigg. L., Temminghoff, E., Tercier-Waeber, M.545 L., Toepperwien, S., Town, R.M., Weng, L. and Xue, H. (2006) Model Predictions of Metal 546 Speciation in Freshwaters Compared to Measurements by In Situ Techniques. Environmental 547 Science \& Technology 40(6), 1942-1949.

548 Valencia-Avellan, M., Slack, R. Stockdale, A. and Mortimer, R.J.G. (2017) Understanding the 549 mobilisation of metal pollution associated with historical mining in a carboniferous upland 550 catchment. Environmental Science: Processes \& Impacts 19(8), 1061-1074.

553

Warnken, K.W., Davison. W. and Zhang, H. (2008) Interpretation of In Situ Speciation Measurements of/norganic and Organically Complexed Trace Metals in Freshwater by DGT. Environmental Science \& Technology 42(18), 6903-6909.

Warnken, KW., Davison, W., Zhang, H., Galceran, J. and Puy, J. (2007) In Situ Measurements of Metal Complex Exchange Kinetics in Freshwater. Environmental Science \& Technology 41(9), 3179-3185.

Warnken, K.W., Lawlor, A.J., Lofts, S., Tipping, E., Davison, W. and Zhang, H. (2009) In Situ Speciation Measurements of Trace Metals in Headwater Streams. Environmental Science \& 559 Technology 43(19), 7230-7236.

Webb, J.A. and Keough, M.J. (2002) Quantification of copper doses to settlement plates in the field using diffusive gradients in thin films. Science of the Total Environment 298(1-3), 207-217.

WFD-UKTAG. (2014) Rivers \& Lakes - Guide to the Metal Bioavailability Assessment Tool (Mstandard-methods-203/tags/bioavailability-assessment-tool-205, [Accessed 28 March 2016]. 
566 WFD-UKTAG. (2009a) Desk top study to evaluate options outside BLM thresholds (low pH 567 and low calcium issues). Project No. SC080021/8d. [Online]. Available from: 568 http://www.wfduk.org/resources\%20/desk-top-study-evaluate-options-outside-blm-

569 thresholds-low-ph-and-low-calcium-issues, [Accessed 24 March 2016].

570 WFD-UKTAG. (2009b) Using biotic ligand models to help implement environmental quality 571 standards for metals under the Water Framework Directive. Science Report 572 SC080021/SR7b. [Online]. Available from: http://www.wfduk.org/resources\%20/using-biotic573 ligand-models-help-implement-eqs-metals, [Accessed 24 March 2016].

574 Yin, H., Cai, Y., Duan, H., Gao, J. and Fan, C. (2014) Use of DGT and conventional methods 575 to predict sediment metal bioavailability to a field inhabitant freshwater snail (Bellamya 576 aeruginosa) from Chinese eutrophic lakes. Journal of Hazardous Materials 264, 184-194.

577 Zhang, H. and Davison, W. (2015) Use of diffusive gradients in thin-films for studies of 578 chemical speciation and bioavailability. Environmental Chemistry 12(2), 85-101.

579 Zhang, H. and Davison, W. (1995) Performance Characteristics of Diffusion Gradients in Thin 580 Films for the in Situ Measurement of Trace Metals in Aqueous Solution. Analytical Chemistry 581 67(19), 3391-3400.

582

583 